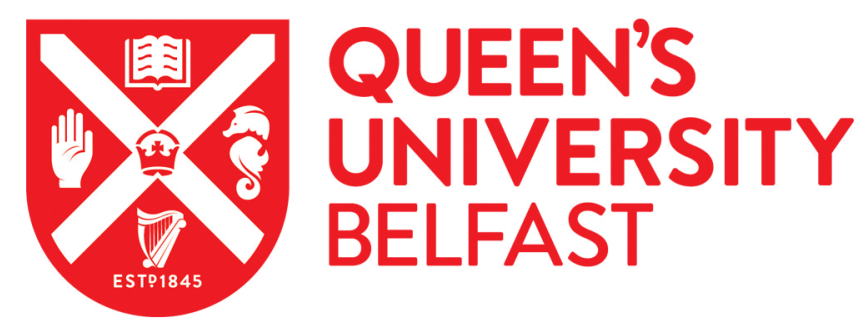

\title{
Life cycle environmental impacts of biogas production and utilisation substituting for grid electricity, natural gas grid and transport fuels
}

Pérez Camacho, M. N., Curry, R., \& Cromie, T. (2019). Life cycle environmental impacts of biogas production and utilisation substituting for grid electricity, natural gas grid and transport fuels. Waste Management, 95, 90101. https://doi.org/10.1016/j.wasman.2019.05.045

Published in:

Waste Management

Document Version:

Publisher's PDF, also known as Version of record

Queen's University Belfast - Research Portal:

Link to publication record in Queen's University Belfast Research Portal

Publisher rights

Copyright 2019 Elsevier.

This manuscript is distributed under a Creative Commons Attribution-NonCommercial-NoDerivs License

(https://creativecommons.org/licenses/by-nc-nd/4.0/), which permits distribution and reproduction for non-commercial purposes, provided the author and source are cited.

\section{General rights}

Copyright for the publications made accessible via the Queen's University Belfast Research Portal is retained by the author(s) and / or other copyright owners and it is a condition of accessing these publications that users recognise and abide by the legal requirements associated with these rights.

Take down policy

The Research Portal is Queen's institutional repository that provides access to Queen's research output. Every effort has been made to ensure that content in the Research Portal does not infringe any person's rights, or applicable UK laws. If you discover content in the Research Portal that you believe breaches copyright or violates any law, please contact openaccess@qub.ac.uk. 

.

Life cycle environmental impacts of biogas production and utilisation substituting for grid electricity, natural gas grid and transport fuels.

$$
\text { María Natividad Pérez-Camacho }{ }^{\mathrm{a}, \mathrm{b}} \text {, Robin Curry }{ }^{\mathrm{a}, \mathrm{b}} * \text {, Thomas Cromie }{ }^{\mathrm{a}, \mathrm{c}}
$$

${ }^{\mathrm{a} C e n t r e ~ f o r ~ A d v a n c e d ~ S u s t a i n a b l e ~ E n e r g y ~(C A S E), ~ D a v i d ~ K e i r ~ B u i l d i n g, ~ S t r a n m i l l i s ~ R o a d, ~}$ Belfast, BT9 5AG, Northern Ireland

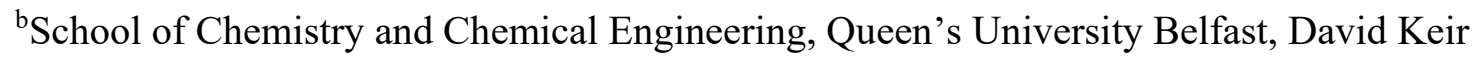 \\ Building, Stranmillis Road BT9 5AG, Belfast, Northern Ireland, UK
}

`AgriAD Power LTD, 31 Reservoir Road, Banbridge, BT32 4LD, Northern Ireland, UK (1)

*Corresponding author r.curry@qub.ac.uk

In this study, life cycle analysis (LCA) has been applied to evaluate the environmental impacts of biogas production and utilisation substituting for grid electricity, natural gas grid and transport fuels, with a focus on Greenhouse Gas (GHG) emissions. The results demonstrate significant reductions in greenhouse gas emissions for the biogas as a fuel scenario due to the displacement of fossil petrol and diesel fuels (scenario 3), with savings of between 524 and $477 \mathrm{~kg}$ of $\mathrm{CO}_{2}$ equivalent (per MWh of energy provided by the fuels). The utilisation of biogas for electricity generation saves around $300 \mathrm{~kg}$ of $\mathrm{CO}_{2}$ equivalent per $\mathrm{MWh}$ of electricity injected into the grid (scenario 1), while Scenario 2, the upgrading of biogas to biomethane and its injection into the gas grid for heating saves $191 \mathrm{~kg}$ of $\mathrm{CO}_{2}$ equivalent (per MWh of energy generated by the biomethane).

The results emphasise the benefits of using life cycle analysis to provide an evidence based for 
bioenergy policy. The limitations of the research are identified and recommendations made for future research priorities to further the use of LCA in the evaluation of bioenergy systems.

\section{Key words:}

Biogas, biomethane, life-cycle analysis, bioenergy.

\section{Introduction}

The coming into effect of the Paris Agreement under the United Nations Framework Convention on Climate Change in 4 November 2016, has seen increased actions from signatories throughout the world to reduce greenhouse gas (GHG) emissions (Nations, 2015). Within the European Union, the 20:20:20 package has set targets of 20\% cut in greenhouse gas emissions (from 1990 levels), $20 \%$ of EU energy from renewables and $20 \%$ improvement in energy efficiency. In addition, member states have binding annual targets until 2020 for cutting emissions in sectors such as housing, agriculture, waste and transport (excluding aviation) (Commission, 2010). In 2014, Northern Ireland produced an estimated 20.3 million tonnes of $\mathrm{CO}_{2}$ equivalent, and accounted for $4 \%$ of the total greenhouse gas (GHG) emissions in the UK, while only accounting for around $2.8 \%$ of the population of the UK. The agri-food sector in NI accounts for a much higher proportion of the economy than the UK average, as it is the region's largest employer and accounts for a much higher proportion of the regions total GHG emissions ( $29 \%$ as opposed to $9 \%$ in the rest of the UK (Committee, on, Climate, \& Change, 2016)The second largest contributor to GHG emissions in Northern Ireland is the transport sector, which accounted for 21\% of the emissions in 2014 (Department for Agriculture, 2018). In Northern Ireland, transport is closely linked to agriculture, with heavy duty vehicles used both by the agri-food industry, processors and retailers (Blades et al., 2017). 
45

\section{Anaerobic digestion}

Anaerobic Digestion (AD) is a biochemical process involving the breakdown of organic materials into biogas, comprising approximately $60 \%$ methane $40 \%$ carbon dioxide (along with trace gases such as hydrogen sulphide and water) (AEBIOM, 2010) and a partially stabilised digestate comprising microbial biomass and undigested feedstock from the digestion process with a range of applications (Chen, Cheng, \& Creamer, 2008). The high calorific value of biogas has seen its potential highlighted as a central element of climate change and renewable energy policies in many countries (N. Curry \& Pillay, 2012) and also as way of mitigating GHG emissions from farming/food production (J Bacenetti et al., 2016), and this in turn has led to increased levels of research into the $\mathrm{AD}$ process itself, leading to steady progress in improving the efficiency of the process (Jin, Li, \& Li, 2016) (Zhen, Lu, Kato, Zhao, \& Li, 2017).

Biogas production has developed rapidly over the last 10 years, particularly in Europe, with Germany having 10,212 plants in operation in 2016 (International Energy Authority, 2016). In Northern Ireland biogas production from AD has grown by over 2,000\% in recent years, with 24 new plants being commissioned since 2015 and there are currently 103 AD sites either in construction or already approved in the region (Anaerobic-digestion.com, 2018). Biogas can be utilised in a number of ways, with the current most common use being in gas engines for combined heat and power (CHP), with the electricity produced usually injected into the grid and a proportion of the heat used on site (Holm-Nielsen, Al Seadi, \& Oleskowicz-Popiel, 2009). 
However, the biogas can also be upgraded for other utilisation options such as biomethane or biodiesel as part of a wider bioenergy system (Murphy, Devlin, Deverell, \& McDonnell, 2014), or utilised for producing energy and chemicals within the biorefinery concept (Cherubini, 2010).

In Europe in 2013, more than $90 \%$ of biogas was used for electricity generation (IRENA, 2017). However, utilisation options for biogas vary greatly between countries in Europe, with Sweden using $63 \%$ of its biogas production as automotive fuel in 2015 (International Energy Authority, 2016).

Upgrading of biogas to biomethane removes the $\mathrm{CO}_{2}$ and impurities in biogas, bringing the methane content up to that of natural gas, making it interchangeable with natural gas as a fuel, and opening up a wider range of utilisation pathways such as injection into the grid (Starr, Villalba, \& Gabarrell, 2015), use as Sustainable Natural Gas (SNG) in vehicles (IRENA, 2017) or integration with other biochemical conversion pathways for the production biohydrogen or biohythane (Han \& Shin, 2004) (Ghimire et al., 2017). However, this divergence of utilisation pathways creates challenges for policy makers attempting to evaluate which of the pathways might be optimal for their conditions (Gonzalez-Salazar et al., 2016). To support the evaluation of these pathways and provide an evidence base for renewable energy policy, decision-support tools are needed, and one of the most commonly applied is life cycle analysis (McKone et al., 2011). Although data has been collected from an operating biogas plant in Northern Ireland for which the models have been built, the scenarios to be presented can also be applied in other regions having biogas plants as a source of energy and other product production.

\section{Life cycle analysis}


The rapid development and divergence of biogas utilisation pathways has seen an increased interest in the evaluation of the environmental performance of these systems. Life cycle analysis (LCA) is a method for evaluating the environmental performance of products processes or technological systems (Heijungs, Huppes, \& Guinée, 2010). LCA quantifies the material and energy inputs and outputs over the entire life cycle of a product or process and has been widely used in the evaluation of bioenergy systems. A previous use of LCA for the evaluation of a bioenergy/bioeconomy system by the authors, demonstrated the reductions in GHG emissions which could achieved through the substitution of food wastes for traditional AD feedstocks and the very significant additional reductions from the diversion of the food waste from landfill (PérezCamacho, Curry, \& Cromie, 2017).

However, this also demonstrates a challenge of applying LCA the to 'multifunction' systems, for example, those that include the dual function of waste management and secondary material or renewable energy production (Nakatani, 2014). In particular, the choice of functional unit (Heijungs \& Guinée, 2007) (Reap, Roman, Duncan, \& Bras, 2008), for utilising waste feedstocks to produce multiple energy pathways or energy carriers. This may go some way to explaining the variations in the reported environmental performance of systems, which may be attributed to the choice of functional unit (S Choudhary et al., 2014) differences in cultivation systems, location, feedstocks (Dressler, Loewen, \& Nelles, 2012) (Ertem, Martinez-Blanco, Finkbeiner, Neubauer, \& Junne, 2016) and/or final use of the energy and management systems for the digestate (Berglund \& Börjesson, 2006) (Dressler et al., 2012). Czyrnek-Delêtre et al have highlighted the particular challenges in applying LCA to bioenergy systems and have made recommendations for addressing these, including that results should be reported using more than one functional unit (CzyrnekDelêtre, Smyth, \& Murphy, 2017). 


\section{Aims and objectives.} The aim of this study is to evaluate the life cycle environmental impacts associated with three production and utilisation scenarios for biogas from anaerobic digestion, namely:

Scenario 1: biogas utilisation in CHP plant for electricity production;

Scenario 2: biogas upgrading and injection to gas grid for heating; and

Scenario 3: biogas upgrading for use as fuel in vehicles.

These three scenarios were chosen to reflect the divergence of utilisation pathways offered by the upgrading of biogas to biomethane and the challenges this presents for the application of LCA to evaluating bioenergy systems. In addition, the evaluation included two sensitivity analyses, namely:

- Sensitivity analysis of a range of biogas upgrading technologies; and

- Sensitivity analysis of a range of fuel mixes in vehicles.

The following objectives underpinned this aim:

- To identify optimal utilisation pathways for biogas production and utilisation, with a focus on GHG mitigation;

- To provide an evidence-base for the development of renewable energy policy at a regional level; and

- To identify future research needs to further the use of Life Cycle Analysis in the evaluation of bioenergy systems.

We believe that the analysis combines a number of novel elements including: 
- Analysis based on an operational biogas/bioenergy facility, using primary data for both plant operation and feedstocks; and

- Analysis of vehicle fuel substitution based on operational dual-fuel HGV trials (Blades et al., 2017).

This article addresses issues of current interest to both researchers and policy makers. Work carried out as part of the Northern Ireland Biogas Research Action Plan has quantified the available feedstocks for AD in Northern Ireland and provided estimates of the biogas and energy potential of these feedstocks and possible reductions in greenhouse gas emissions from 'traditional' biogas to CHP (R. Curry et al., 2018). However, there has been significant recent research which has focussed on the potential for biomethane as sustainable transport biofuel in Ireland (Korres, Singh, Nizami, \& Murphy, 2010), while research carried out for Ervia/Gas Networks Ireland, has highlighted the potential of biomethane in decarbonising domestic heating in Ireland (KPMG, 2018). As such, this article builds on and contributes to this debate by applying Life Cycle Analysis to evaluate the environmental costs and benefits associated with three biogas production and utilisation pathways, with the purpose of contributing to the evaluation of developing and diverging biogas utilisation pathways, providing an evidence base for renewable energy policy and contributing to the ongoing methodological development of the LCA methodology for the evaluation of bioenergy systems.

\section{Materials and methods}

\subsection{Modelling scope of the study}

Life cycle analysis (LCA) has been applied to evaluate the environmental impacts of three utilisation options for the biogas produced in an operational industrial anaerobic digestion plant 
located in Northern Ireland. The study has been carried out following the ISO 14040/14044 standard (ISO, 2006). For modelling purposes of the LCA, SimaPro version 8.3 with Ecoinvent database 3.3 have been used. Details of the methodology, plant systems and assumptions are described in the following sections.

\subsection{Goal and scope of the study}

This study evaluates the environmental impacts of three utilisation scenarios for the biogas produced in the $\mathrm{AD}$ of organic wastes (with a feedstock of cattle slurry and grass silage), using life cycle analysis. The environmental impacts of the three systems are considered based on an operational industrial biogas plant in Northern Ireland. Scenario 1 represents the utilisation of the biogas in a CHP plant to produce electricity to inject into the grid (with some electricity used for plant operation); scenario 2 considers the upgrading of the biogas to biomethane for its injection into the gas grid for heating; scenario 3 considers the upgrading of the biogas to biomethane and its utilisation as a fuel for vehicles. Figure 1 illustrates the process flow diagram and system boundaries for the three scenarios.

\section{Functional unit and system boundaries.}

The functional unit (FU) chosen for the analysis is $1 \mathrm{MWh}$ of energy. The rationale for this choice of $\mathrm{FU}$ is that the aim of the research is to evaluate the performance of three energy-carriers produced from anaerobic digestion of biogas, namely electricity, biomethane substituting for NG and biomethane substituting for vehicle fuel. Choudhary et al. demonstrated that the choice of FU can have a significant impact on the results of the evaluation of between different bioenergy systems (S. Choudhary et al., 2014) and other studies have chosen different functional units. K. S. Woon et al. who evaluated the three similar scenarios chose one tonne of feedstock as their functional unit (K. S. Woon, I. M. Lo, S. L. Chiu, \& D. Y. Yan, 2016) while G. Fiorentino et al. 
looking at the valorisation of municipal solid waste also used one tonne of waste (Fiorentino, Ripa, Protano, Hornsby, \& Ulgiati, 2015). An interesting analysis by Dressler et at, used two different functional units ( $\mathrm{kg}$ and $\mathrm{kWh}$ ) (Dressler et al., 2012) to assess the environmental performance of biogas to CHP (see recommendations for future research priorities)

\section{Description of the system}

Figure 1 illustrates the system boundaries for the three scenarios considered where maize/grass silage and cattle slurry are used for the production of biogas which is then converted to electricity and heat in a combined heat and power (CHP) plant (scenario 1) or upgraded to biomethane (98\% $\mathrm{v} / \mathrm{v}$ of purity) for its injection into the gas grid (scenario 2) or its use as a fuel for an Iveco Stralis truck (scenario 3) (The Iveco Stralis truck was used as data from operational trials on dual-fuel usage was available upon agreement with the School of Mechanical Engineering (See acknowledgements) . The CHP produces enough electricity to cover the plant parasitic load and the remainder is fed to the electricity grid.

Figure 1.

The system boundaries of the electricity provided by the national grid include the emissions during the production of the respective energy sources. For natural gas usage and vehicle fuels, the emissions are from fuel combustion and exclude emissions associated with vehicle manufacturing, to facilitate comparison with the results of other studies which have excluded these (K. Woon, I. Lo, S. Chiu, \& D. Yan, 2016)

The operational AD facility for the study uses grass/maize silage and cattle slurry (GS + CS) as feedstocks. The feedstock for the plant goes through the digester feed, the macerator and the solid 
feeding system (Trioliet $\left.{ }^{\circledR}\right)$ before it is pumped into 2 anaerobic digester tanks (maintained at mesophilic regime, $\left.40^{\circ} \mathrm{C}\right)$.

For the purpose of the evaluation of the scenarios (S), biogas is either transferred to the CHP unit (S1) or to the biogas upgrading system (S2 and S3). If all the biogas is used for electricity generation, the average total electricity produced per day is $8880 \mathrm{kWh}$ with a daily export to the grid of $6560 \mathrm{kWh}$ and the rest $(2320 \mathrm{kWh} /$ day $)$ used in the maintenance of the plant. This is equivalent to $26 \%$ of electricity output. There is an average daily heat production of $9052 \mathrm{kWh}$, of which $3017 \mathrm{kWh}$ are used for maintaining the plant at $40^{\circ} \mathrm{C}$.

\section{Biogas upgrading.}

The technology chosen for biogas upgrading is membrane separation which is a relatively new although it has recently gained a significant market application in recent years (IRENA International Renewable Energy Agency, 2017).

\section{Fossil fuel alternative}

To compare the biogas utilisation options, alternate scenarios were modelled into SimaPro 8.3 to calculate the environmental impact substituting for: electricity from the grid, natural gas grid and diesel and petrol as fuels for vehicles.

These routes compared the $1 \mathrm{MWh}$ of electricity from the grid, $1 \mathrm{MWh}$ provided by the natural gas grid or the fuel equivalent that provides $1 \mathrm{MWh}$ of energy. This means the LCA study has been carried out, comparing (1) $1 \mathrm{MWh}$ of electricity production from the grid or from the biogas CHP; (2) $1 \mathrm{MWh}$ provided by the natural gas grid or the upgraded biogas (biomethane actually) equivalent gas amount and; (3) using the also equivalent $1 \mathrm{MWh}$ of energy provided by a certain amount of fuel for vehicle utilisation (diesel/petrol or biomethane). 
The data for modelling were taken from the Ecoinvent 3.3 database included in the SimaPro 8.3 software.

\subsection{Life Cycle Inventory Data}

The inventory data used to model the environmental impacts of the three biogas utilisation options, namely (1) AD electricity; (2) biomethane to grid and; (3) biomethane as a fuel are summarised in Table S1 of the Supplementary Information (SI) document. The data on plant operation was provided by the $\mathrm{AD}$ plant owner.

The biomethane balance was calculated using preliminary data from the AD plant owner while the energy consumption in the upgrading system was assumed as $0.4 \mathrm{kWh}$ per $\mathrm{m}^{3}$ of biomethane, which was calculated from Patterson et al., 2011 (Patterson, Esteves, Dinsdale, \& Guwy, 2011). The compression of biomethane was assumed to consume $0.35 \mathrm{kWh}$ per $\mathrm{m}^{3}$ of biomethane (Smyth, Smyth, \& Murphy, 2010). Others sources reviewed which provided similar values included (Evonik, 2016).

Additional inventory data have been provided on the allocation method followed within the biogas/digestate production (50:50); cattle slurry/milk production (3:97); and electricity/heat generation (75:25) within the CHP. The additional inventory data provides sources for all of the data and assumptions used to compile the inventory and an evaluation of these sources (See SI document).

\subsection{Life Cycle Impact Assessment}

The three scenarios for anaerobic digestion and biogas utilisation have been modelled using SimaPro LCA software, version 8.3. The impacts have been estimated using the ReCiPe method, Midpoint Hierarchical V1.13. 2017. (PRé, 2019). The ReCiPe method, at the midpoint level, was 
followed to estimate the 18 impact categories which are addressed as follows: climate change, ozone depletion, terrestrial acidification, fresh water eutrophication, marine eutrophication, human toxicity, photochemical oxidant formation, particulate matter formation, terrestrial ecotoxicity, freshwater ecotoxicity, marine ecotoxicity, ionising radiation, agricultural land occupation, urban land occupation, natural land transformation, water depletion, metal depletion and fossil depletion. The ReCiPe midpoint method and impact areas were chosen to allow the analysis to spotlight single impact categories which might be of interest to policy makers and other researchers (Huijbregts et al., 2017). For example, the choice of terrestrial eutrophication directly informs a key issue relating to biogas production in a region which is a Nitrate Vulnerable Zone (NVZ), that of potential run-off from digestate application to land.

\section{Results}

The environmental impacts related to the three scenarios considered in this paper are shown in next sections. Tables 2 to 4 in the SI document summarise the results for all the impact categories while Figures 3, 5 and 7 illustrate three impact categories: global warming potential $\left(\mathrm{kg} \mathrm{CO}_{2} \mathrm{eq}\right)$, particulate matter formation ( $\left.\mathrm{kg} \mathrm{PM10} \mathrm{eq)} \mathrm{and} \mathrm{terrestrial} \mathrm{acidification} \mathrm{(} \mathrm{kg} \mathrm{SO}_{2} \mathrm{eq}\right)$ and two damage categories: freshwater and marine eutrophication ( $\mathrm{kg} \mathrm{P}$ eq and $\mathrm{kg} \mathrm{N}$ eq respectively) as these categories were of particular interest in Northern Ireland as the entire region is designated as a Nitrate Vulnerable Zone (NVZ) under the Nitrates Directive (91/676/EEC) (Department of Agriculture, 2019).

\subsection{Scenario 1: utilisation of the biogas for electricity production}


Figure 2 illustrates scenario 1, where grass and maize silage and cattle slurries were anaerobically digested and the resultant biogas is used in a combined heat and power plant to produce electricity and heat.

Table S2 (SI document) summarises the emissions for all the impact categories considered in the ReCiPe method plus the savings for scenario 1. A negative value of the savings indicates that the emissions of the biogas utilisation option are lower than the avoided impacts resulting from the fuel replacement which provides an overall positive environmental performance for the scenario, and vice versa for a positive value.

\section{Figure 2.}

There are 7 out of the 18 impact categories where the electricity from the AD plant has a lower environmental impact than the electricity from the national grid while in other 7 the impact is of a similar value. Only 4 impact categories showed a higher impact for the AD electricity, with the most significant being agricultural land occupation.

Figure 3 shows five of the most relevant environmental impact categories considered for the production of $1 \mathrm{MWh}$ of electricity: climate change, terrestrial acidification, freshwater and marine eutrophication and particulate matter formation.

Figure 3.

In the climate change impact category, the results of the GHG emissions are expressed in $\mathrm{kg}$ of $\mathrm{CO}_{2}$ eq (carbon dioxide equivalent), with GWP values over a 100-year time horizon (Intergovernmental Panel on Climate Change, 2006). Terrestrial acidification is expressed in $\mathrm{kg}$ of $\mathrm{SO}_{2}$ eq, freshwater and marine eutrophication as $\mathrm{kg}$ of $\mathrm{P}$ and $\mathrm{N}$ eq respectively and particulate matter formation as kg of PM10 eq (Intergovernmental Panel on Climate Change, 2006). 
The production of $1 \mathrm{MWh}$ of electricity injected into the grid from $\mathrm{AD}$, generates $302 \mathrm{~kg}$ of $\mathrm{CO}_{2}$ eq which is lower than the value of the electricity from the grid $(597 \mathrm{~kg}$ of CO $2 \mathrm{eq})$. The utilisation of electricity from $\mathrm{AD}$ could then save $294 \mathrm{~kg}$ of $\mathrm{CO}_{2}$ eq per $\mathrm{MWh}$ of electricity injected into the grid. This result was compared to other studies although direct comparisons are difficult due to feedstock and functional unit variations. Other authors using the same functional unit found similar results, for example, Dressler et al. studied biogas production from maize and its conversion to electricity obtaining emissions of 248 to $281 \mathrm{~kg}$ of $\mathrm{CO}_{2}$ eq per $\mathrm{MWh}$ of electricity generated (Dressler et al., 2012). Studies performed in Italy for the anaerobic digestion of maize silage and pig slurry produced values ranging from 294 to $350 \mathrm{~kg} \mathrm{CO}_{2}$ eq per MWh of electricity produced (J. Bacenetti, Negri, Fiala, \& Gonzalez-Garcia, 2013).

As set out in Figure 3 and Table S2 (SI document), electricity from the grid has similar terrestrial acidification potential (2.75 vs $2.54 \mathrm{~kg}$ of $\left.\mathrm{SO}_{2} \mathrm{eq}\right)$ and freshwater eutrophication $(0.19 \mathrm{vs} 0.11 \mathrm{~kg}$ of P eq). Marine eutrophication ( $0.1 \mathrm{vs} 0.35 \mathrm{~kg} \mathrm{~N}$ eq). Particulate formation PM10 are similar in both cases, being slightly higher for electricity from biogas ( 1 vs $0.8 \mathrm{~kg}$ of PM10 eq). Fusi et al., reported lower acidification and eutrophication potential for grid electricity due to the maize cultivation which contributes significantly to these impacts (Fusi, Bacenetti, Fiala, \& Azapagic, 2016), however, they did not report on particulate matter impact (PM10). Woon et al. reported higher values of particulate matter formation for the electricity from the AD of food waste (K. S. Woon et al., 2016), although the possible origin was not identified.

\subsection{Scenario 2: upgrading of the biogas to natural gas standards to use as gas to grid for} heating

The system boundaries for scenario 2 are illustrated in Figure 4. In this case, the biogas produced in the $\mathrm{AD}$ of grass/maize silage and cattle slurry is upgraded to biomethane using membrane 
separation technology. The system uses the electricity needed for upgrading from the electricity generated in the CHP plant. The environmental impact of both upgraded biomethane and natural gas are compared and shown Figure 4 and Table S3 (SI document).

Figure 4.

In Table S3 (SI document), the comparison between the environmental impacts of natural gas and biomethane and the savings from the utilisation of biomethane are summarised. The production and utilisation of $1 \mathrm{MWh}$ equivalent of biomethane from $\mathrm{AD}$, generates $259 \mathrm{~kg}$ of $\mathrm{CO}_{2}$ eq which is lower than the value of fossil natural gas ( $450 \mathrm{~kg}$ of $\mathrm{CO}_{2}$ eq). Biomethane could then save 191 $\mathrm{kg}$ of $\mathrm{CO}_{2}$ eq per $\mathrm{MWh}$ of biomethane. Natural gas from the grid has lower freshwater eutrophication ( 0.00 vs $0.05 \mathrm{~kg} \mathrm{P}$ eq), marine eutrophication ( $0.02 \mathrm{vs} 0.016 \mathrm{~kg}$ of N eq) than biomethane. Particulate matter formation and terrestrial acidification are higher for natural gas from the grid. Jury et al. reported that biogas has a higher contribution to human health and ecosystem quality damages than natural gas but lower contribution to global warming potential and consumption of resources. A higher contribution to aquatic acidification and eutrophication from biogas production is likely to be due to the ammonia emissions from farming, and possibly digestate storage (Jury, Benetto, Koster, Schmitt, \& Welfring, 2010). Similar effects were found by Styles et al. (Styles, Dominguez, \& Chadwick, 2016). Figure 5 shows five of the most relevant environmental impact categories considered for the production of $1 \mathrm{MWh}$ of electricity: climate change, terrestrial acidification, freshwater and marine eutrophication and particulate matter formation.

Figure 5 .

\subsection{Scenario 3: upgrading of the biogas for its utilisation as a vehicle fuel}


The system boundaries for scenario 3 are illustrated in Figure 6.

Figure 6.

Table S4 (SI document) summarises the 18 impact categories considered in the ReCiPe method, Midpoint Hierarchical used in SimaPro while Figure 7 illustrates the most relevant impact categories.

The utilisation of biomethane as fuel for vehicles saves around $500 \mathrm{~kg}$ of $\mathrm{CO}_{2}$ eq per $\mathrm{MWh}$ equivalent compared to petrol or diesel, with the savings slightly higher for diesel fuel. The particulate matter formation is of the same order of magnitude for diesel and petrol and much lower for biomethane. Figure 7 shows five of the most relevant environmental impact categories considered for the production of $1 \mathrm{MWh}$ of electricity: climate change, terrestrial acidification, freshwater and marine eutrophication and particulate matter formation.

\section{Figure 7.}

The results are in accordance with Woon et al. (K. S. Woon et al., 2016) who found the scenario of fuel utilisation as having the greatest impact in terms of GHG emissions reductions, although they obtained lower values for terrestrial acidification savings ( $-0.210 \mathrm{~kg} \mathrm{SO}$ eq/ tonne food waste) and higher values ( $+0.25 \mathrm{~kg}$ PM10 eq/ tonne food waste) for particulate matter formation, we had more reduction of terrestrial acidification $\left(-1.98 \mathrm{~kg} \mathrm{SO}_{2} \mathrm{eq} / \mathrm{MWh}\right.$ of diesel which is equivalent to $-0.680 \mathrm{~kg} \mathrm{SO} 2 \mathrm{eq} /$ tonne food waste and $-0.80 \mathrm{~kg}$ PM10 eq/ MWh of diesel equivalent to $-0.275 \mathrm{~kg}$ PM10 eq/ tonne food waste). Our numbers have been converted from Woon et al., 2016 by taking a production of $17.2 \mathrm{MWh}$ /day of biomethane minus $1.316 \mathrm{MWh}$ /day used for upgrading and compression being produced from 46.2 tonne of food waste per day.

\section{Sensitivity Analysis}


Two sensitivity analyses were performed, the first looked at was the variation in the energy use of upgrading technologies (electricity) and the second sensitivity analysis evaluates the environmental impacts of different utilisation rates of biomethane to petrol and diesel in the dual fuel vehicle. The approach used for the sensitivity analysis of energy use for upgrading was to use the range of estimates for electricity use from the literature, while for analysis of fuel utilisation ratios, a range of hypothetical scenarios were adopted (see below).

\subsection{Sensitivity analysis on biomethane upgrading technologies.}

The upgrading of biogas to biomethane can be achieved via a range of technologies which include adsorption being pressure swing adsorption the most common (PSA); absorption with water (water scrubbing), polyethylene glycol (organic physical scrubbing) and mono ethanol amine, MEA (chemical scrubbing); by permeation or membrane separation; and cryogenic separation (Persson, Jonsson, \& Wellinger, 2006), (Petersson \& Wellinger, 2009), (Pertl, Mostbauer, \& Obersteiner, 2010) and (Patterson et al., 2011).

A key consideration when selecting the technology to use for the upgrading of biogas is the electricity consumed at this stage. The performance related to electricity consumption for each of the technologies considered is summarised in Table 5. According to the electricity consumption for each technology, a sensitivity analysis was carried out. The electricity requirement for each technology has been taken from a summary of energetic requirements of biogas upgrading from Patterson et al. (Patterson et al., 2011).

The results from the sensitivity analysis are summarised in Table S6 (SI document). A key point from the sensitivity analysis is that the variations in electricity use for each technology are not reflected in variations in the GHG emissions. For example, the electricity use ranges from 0.26 to 
$0.47 \mathrm{kWh} / \mathrm{m}^{3}$ of biomethane, however, the variation in, for example, GHG emissions (climate change) only vary from 255.51 to $261.59 \mathrm{~kg} \mathrm{CO} 2 \mathrm{eq} / \mathrm{MWh}$ of biomethane obtained. One possible explanation for this is that the upgrading process is only a small part of overall plant electricity use and also that the electricity is coming from plant parasitic load.

While beyond the scope of this analysis, an additional factor with upgrading processes is differing levels of $\mathrm{CH}_{4}$ slippage, which could affect the environmental impacts, particularly with respect to GHG-eq.

4.2.Sensitivity analysis on fuel rates.

A sensitivity analysis to illustrate the environmental effect of a dual fuel vehicle utilisation with different rates of biomethane to diesel was performed. The cases studies were the utilisation of ratios of biomethane to diesel (bioM: diesel) of 100: 0 (which is the baseline considered in scenario 3); 70: 30; 50: 50; 30: 70 and 0: 100 (case where only diesel was used).

Table S7 (SI document) shows the results from the calculation with SimaPro 8.3. This analysis showed higher environmental impact in all categories as the rate of diesel fuel increases in the total fuel combination of the duel fuel system vehicle.

\section{Discussion and conclusions}

The environmental impacts of three utilisation scenarios for biogas from anaerobic digestion have been evaluated using life cycle analysis. The results of the analysis have been summarised in Figures 7, 8 and 9 and Table S8 (SI document).

\section{Figure 7}

Figure 8. 
391 The aim of this study was to evaluate the life cycle environmental impacts associated with three 392 production and utilisation pathways for biogas from anaerobic digestion, with the underlying 393 objectives of identifying optimal utilisation pathways (with a focus on GHG emissions reductions), 394 informing renewable energy policy development and identifying future research needs. While all 395 three of the scenarios demonstrate reductions relative to the non-renewable alternative, the upgrading of biogas to biomethane substituting for petrol or diesel use in transport provides the greatest reductions in environmental impacts, both in terms of GHG emissions, but also particulates.

These results are in line with the results from similar studies, for example, Murphy et al. found

400

401 that biomethane from grass achieved a reduction of $75 \%$ compared to diesel for transport (Korres et al., 2010), compared to a percentage reduction from this study in the range of $73 \%$ to $75 \%$.

Research by Poschl et al. demonstrated that the energy efficiency of the system improved by up to $65 \%$ when natural gas was substituted instead of electricity and also that energy efficiency could be further enhanced by $5.1-6.1 \%$ through recovery of residual biogas from enclosed digestate storage units (Pöschl, Ward, \& Owende, 2010). Evangelisti et al. make the important point that a critical factor in optimising utilisation pathways is the quantity and quality of the energy substituted and it therefore important to define the energy system within which the plant is embedded (Evangelisti, Lettieri, Borello, \& Clift, 2014).

While the focus of the LCA has been GHG mitigation, it has also quantified the reductions in particulate emissions associated with the substitution of biomethane for petrol and diesel fuels, demonstrating reductions of around $73 / 74 \%$. While some sources claim almost zero particulate 
emissions for Compressed Natural Gas (CNG) (Ireland, 2018), it is likely that these claims relate solely to the combustion of the fuel. However, while some of the particulate material occurs from incomplete combustion of Hydrocarbons (HCs) in fuel, lubricating oil and brake and clutch use also contributes to particulate emissions (Heywood, 2018). Additionally, the LCA modelling would include any particulate emissions associated with raw material acquisition and vehicle manufacture (MacLean \& Lave, 2003).

The sensitivity analysis of biogas upgrading technologies indicated that variations in the energy (electricity) requirements for upgrading were not reflected in significant variations in GHG emissions. Possible explanations for this include upgrading being only a small part of overall plant electricity use or that the electricity is coming from plant parasitic load.

Limitations of the research. One area previously identified as a potential limitation is the choice of functional unit in multi-function systems, such as biogas production using waste feedstocks and a range of utilisation pathways. While most LCA researchers provide a clear rationale for their choice of functional unit, the decision will largely be driven by aim or purpose of the LCA. For example, researchers evaluating use of waste feedstocks are likely to choose 1 tonne of waste as their functional unit, (Gentil et al., 2010) (Cherubini, Bargigli, \& Ulgiati, 2008), whereas researchers wishing to evaluate bioenergy systems will chose an energy or energy carrier functional unit (Stephenson et al., 2010). Cherubini offers a useful classification system for functional units by defining them by on the basis of input and output FU's (Cherubini \& Strømman, 2011). Recent research from the EC Joint Research Centre (JRC) has made recommendations for dealing with 'multi-functionality, problems, and warning that without a clear and systematic basis for these choices 'solving multi-functionality problems are likely to produce divergence results' (Pelletier, Ardente, Brandão, De Camillis, \& Pennington, 2015) p75, and this and a range of other 
methodological issues are addressed in the Product Environmental Footprint (PEF) guide, published by the JRC (Manfredi, Allacker, Chomkhamsri, Pelletier, \& de Souza, 2012) An additional possible limitation is 'static' nature of the scenarios when modelling. Heijungs and Guinée have highlighted the dangers of using 'what-if' scenarios when applying LCA to multifunctional systems (Heijungs \& Guinée, 2007). Finally, as with all LCA studies, the issue of how to deal uncertainty arises. The authors hope that the provision of all of the inventory data used in the modelling, combined with the sensitivity analysis will go some way to addressing this (Igos, Benetto, Meyer, Baustert, \& Othoniel, 2018).

\section{Recommendations for future research priorities.}

The aims of this study combined the evaluation of the sustainability of three production and utilisation pathways with identifying future research needs to further the use of LCA in the evaluation of bioenergy systems. One of the key issues is what has been referred to as the changing nature of life cycle assessment, which is challenging traditional LCA classification systems (McManus \& Taylor, 2015). For example, this research combined a retrospective analysis of an existing bioenergy system, with prospective analysis of two hypothetical utilisation pathways. As such, it does not fit comfortably within the convention of classification of LCA as attributional or consequential (Styles et al., 2016), and may more accurately be described as dynamic life cycle assessment (Pehnt, 2006).

The authors have previously recommended as a priority research into guidance on the application of LCA to biogas/bioenergy systems, and believe that the recommendations set out by CzyrnekDelêtre et al. provide a useful platform for future research (Czyrnek-Delêtre et al., 2017), and we would recommend that future LCA's of bioenergy systems should include sensitivity analyses of both input and output FU's. We would further recommend that all researchers carrying out LCA's 
of biogas/bioenergy systems should provide all underlying Inventory data as Supplemental Information (SI). In addition, while GHG emissions reduction is often the focus of policy-makers, it is important that a full range of impact areas is reported, to avoid burden shifting, particularly when the purpose of the evaluation is to inform policy (Sala, Reale, Cristobal-Garcia, Marelli, \& Pant, 2016). With the growing divergence of bioenergy utilisations pathways, it is becoming increasingly important that the evaluation of these systems includes other bioenergy technologies such as gasification/pyrolysis/fermentation/algae, to enable potential synergies to be identified, and we believe the use of the biorefinery concept offers a useful framework for this (PérezCamacho et al., 2017). The authors hope that the issues identified and discussed in this paper can provide insights for other researchers and help set out the priorities for research to support this important research and policy area.

\section{Acknowledgements}

This research was funded by the Centre for Advanced Sustainable Energy (CASE) and carried out as part of the 'Biogas to Biorefinery' project at Queen's University Belfast. CASE is funded through the Invest NI Northern Ireland Competence Centre programme, which bridges the gap between industry research needs and academic research offerings. Thanks to AgriAD Ltd for providing the data from the anaerobic digestion facility and to Iveco S.p.A, for providing the reference value of biomethane in their dual fuel truck through their collaboration with the School of Mechanical and Aerospace Engineering at Queen's University Belfast.

\section{References}

AEBIOM. (2010). A Biogas Road Map for Europe. Retrieved from Brussels: http://www.4biomass.eu/document/news/AEBIOM Biogas Roadmap.pdf 
Anaerobic-digestion.com. (2018). Anaerobic Digestion in Northern Ireland. Retrieved from https://anaerobic-digestion.com/anaerobic-digestion-plants/anaerobic-digestionireland/anaerobic-digestion-northern-ireland/

Bacenetti, J., Bava, L., Zucali, M., Lovarelli, D., Sandrucci, A., Tamburini, A., \& Fiala, M. (2016). Anaerobic digestion and milking frequency as mitigation strategies of the environmental burden in the milk production system. Science of The Total Environment, 539, 450-459. doi:http://dx.doi.org/10.1016/j.scitotenv.2015.09.015

Bacenetti, J., Negri, M., Fiala, M., \& Gonzalez-Garcia, S. (2013). Anaerobic digestion of different feedstocks: impact on energetic and environmental balances of biogas process. Sci Total Environ, 463-464, 541-551. doi:10.1016/j.scitotenv.2013.06.058

Berglund, M., \& Börjesson, P. (2006). Assessment of energy performance in the life-cycle of biogas $\begin{array}{llll}\text { production. Biomass } 30(3), & \text { 254-266. }\end{array}$ doi:http://dx.doi.org/10.1016/j.biombioe.2005.11.011

Blades, L., Morgana, K., Douglas, R., Glover, S., Rosa, M., Cromiea, C., \& Smyth, B. (2017). Circular BiogasBased Economy in a Rural Agricultural Setting. Paper presented at the 1st International Conference on Sustainable Energy and Resource Use in Food Chains, ICSEF 2017, 19-20 April 2017, Berkshire, UK, Berkshire, UK. https://www.sciencedirect.com/journal/energyprocedia/vol/123/suppl/C

Chen, Y., Cheng, J., \& Creamer, K. (2008). Inhibition of anaerobic digestion process: A review. Bioresource Technology, 99, 4044-4064.

Cherubini, F. (2010). The biorefinery concept: Using biomass instead of oil for producing energy and chemicals. Energy Conversion and Management, 51(7), 1412-1421. doi:http://dx.doi.org/10.1016/i.enconman.2010.01.015

Cherubini, F., Bargigli, S., \& Ulgiati, S. (2008). Life cycle assessment of urban waste management: Energy performances and environmental impacts. The case of Rome, Italy. Waste Management, 28(12), 2552-2564. doi:10.1016/j.wasman.2007.11.011

Cherubini, F., \& Strømman, A. H. (2011). Life cycle assessment of bioenergy systems: State of the art and future challenges. Bioresource Technology, 102(2), 437-451. doi:https://doi.org/10.1016/i.biortech.2010.08.010

Choudhary, S., Liang, S., Cai, H., Keoleian, G., Miller, S., Kelly, J., \& Xu, M. (2014). Reference and functional unit can change bioenergy pathway choices. The International Journal of Life Cycle Assessment, 19(4), 796-805. doi:10.1007/s11367-013-0692-z

Choudhary, S., Liang, S., Cai, H., Keoleian, G. A., Miller, S. A., Kelly, J., \& Xu, M. (2014). Reference and functional unit can change bioenergy pathway choices. doi:10.1007/s11367-013-0692-z)

Commission, E. (2010). EUROPE 2020. A strategy for smart, sustainable and inclusive growth. Retrieved from Brussels: http://eurlex.europa.eu/LexUriServ/LexUriServ.do?uri=COM:2010:2020:FIN:EN:PDF

Committee, on, Climate, \& Change. (2016). The appropriateness of a Northern Ireland Climate Change Act (2015 update). Retrieved from https://www.theccc.org.uk/publication/the-appropriateness-ofa-northern-ireland-climate-change-act/

Curry, N., \& Pillay, P. (2012). Biogas prediction and design of a food waste to energy system for the urban environment. $\quad$ Renewable 41, 200-209. doi:http://dx.doi.org/10.1016/j.renene.2011.10.019

Curry, R., Pérez-Camacho, M., Brennan, R., Gilkinson, S., Cromie, T., Foster, P., . . . Ellis, G. (2018). Quantification of anaerobic digestion feedstocks for a regional bioeconomy. Proceedings of the Institution of Civil Engineers - Waste and Resource Management, 171(4), 94-103. doi:10.1680/jwarm.17.00014 
Czyrnek-Delêtre, M. M., Smyth, B. M., \& Murphy, J. D. (2017). Beyond carbon and energy: The challenge in setting guidelines for life cycle assessment of biofuel systems. Renewable Energy, 105, 436-448. doi:http://dx.doi.org/10.1016/i.renene.2016.11.043

Department for Agriculture, E. a. R. A. (2018). Northern Ireland greenhouse gas inventory 1990-2016 statistical bulletin Retrieved from Belfast: https://www.daerani.gov.uk/sites/default/files/publications/daera/ghg-inventory-statistical-bulletin-2016.pdf

Department of Agriculture, E. a. R. A. (2019). Review of Sensitive Areas. Retrieved from https://www.daera-ni.gov.uk/articles/review-sensitive-areas\#toc-2

Dressler, D., Loewen, A., \& Nelles, M. (2012). Life cycle assessment of the supply and use of bioenergy: impact of regional factors on biogas production. The International Journal of Life Cycle Assessment, 17(9), 1104-1115. doi:10.1007/s11367-012-0424-9

Ertem, F. C., Martinez-Blanco, J., Finkbeiner, M., Neubauer, P., \& Junne, S. (2016). Life cycle assessment of flexibly fed biogas processes for an improved demand-oriented biogas supply. Bioresour Technol, 219, 536-544. doi:10.1016/j.biortech.2016.07.123

Evangelisti, S., Lettieri, P., Borello, D., \& Clift, R. (2014). Life cycle assessment of energy from waste via anaerobic digestion: A UK case study. Waste Management, 34(1), 226-237. doi:http://dx.doi.org/10.1016/i.wasman.2013.09.013

Evonik. (2016). "SEPURAN ${ }^{\circledR}$ Green Membrane technology for upgrading biogas efficiently" Prospect. Retrieved from www.sepuran.com/sites/lists/RE/DocumentsHP/SEPURAN-greenfor-upgradingbiogas-EN.pdf

Fiorentino, G., Ripa, M., Protano, G., Hornsby, C., \& Ulgiati, S. (2015). Life Cycle Assessment of Mixed Municipal Solid Waste: Multi-input versus multi-output perspective. Waste Manag, 46, 599-611. doi:10.1016/j.wasman.2015.07.048

Fusi, A., Bacenetti, J., Fiala, M., \& Azapagic, A. (2016). Life Cycle Environmental Impacts of Electricity from Biogas Produced by Anaerobic Digestion. Front Bioeng Biotechnol, 4, 26. doi:10.3389/fbioe.2016.00026

Gentil, E., Damgaard, A., Hauschild, M., Finnveden, G., Eriksson, O., Thorneloe, S., . . Christensen, T. (2010). Models for waste life cycle assessment: Review of technical assumptions. Waste Management.

Ghimire, A., Kumar, G., Sivagurunathan, P., Shobana, S., Saratale, G. D., Kim, H. W., . . Munoz, R. (2017). Bio-hythane production from microalgae biomass: Key challenges and potential opportunities for algal bio-refineries. Bioresource Technology, 241(Supplement C), 525-536. doi:https://doi.org/10.1016/j.biortech.2017.05.156

Gonzalez-Salazar, M. A., Venturini, M., Poganietz, W.-R., Finkenrath, M., Kirsten, T., Acevedo, H., \& Spina, P. R. (2016). Development of a technology roadmap for bioenergy exploitation including biofuels, waste-to-energy and power generation \& CHP. Applied Energy, 180, 338-352. doi:https://doi.org/10.1016/i.apenergy.2016.07.120

Han, S.-K., \& Shin, H.-S. (2004). Biohydrogen production by anaerobic fermentation of food waste. International Journal of Hydrogen Energy, 29(6), 569-577. doi:https://doi.org/10.1016/j.ijhydene.2003.09.001

Heijungs, R., \& Guinée, J. B. (2007). Allocation and 'what-if' scenarios in life cycle assessment of waste management systems. Waste Management, 27(8), 997-1005. doi:10.1016/j.wasman.2007.02.013

Heijungs, R., Huppes, G., \& Guinée, J. B. (2010). Life cycle assessment and sustainability analysis of products, materials and technologies. Toward a scientific framework for sustainability life cycle analysis. Polymer Degradation and Stability, 95(3), 422-428. doi:https://doi.org/10.1016/j.polymdegradstab.2009.11.010

Heywood, J. (2018). Internal Combustion Engine Fundamentals (R. Argentieri Ed. 2nd ed.): McGraw-Hill. 
Holm-Nielsen, J. B., Al Seadi, T., \& Oleskowicz-Popiel, P. (2009). The future of anaerobic digestion and biogas utilization. Bioresource Technology, 100(22), 5478-5484. doi:http://dx.doi.org/10.1016/i.biortech.2008.12.046

Huijbregts, M. A. J., Steinmann, Z. J. N., Elshout, P. M. F., Stam, G., Verones, F., Vieira, M., . . van Zelm, R. (2017). ReCiPe2016: a harmonised life cycle impact assessment method at midpoint and endpoint level. The International Journal of Life Cycle Assessment, 22(2), 138-147. doi:10.1007/s11367-0161246-y

Igos, E., Benetto, E., Meyer, R., Baustert, P., \& Othoniel, B. (2018). How to treat uncertainties in life cycle assessment studies? The International Journal of Life Cycle Assessment. doi:10.1007/s11367-0181477-1

Intergovernmental Panel on Climate Change, I. (2006). 2006 IPCC guidelines for national greenhouse gas inventories. Waste, vol. 5.

International Energy Authority, B. T. (2016). Country Report Summaries 2016. Retrieved from file:///C:/Users/Robinc/Downloads/IEA\%20Bioerg+T37CRS+2016+FINAL.pdf

Ireland, G. N. (2018, July 2018). Transport and natural gas. Why choose CNG as a transport fuel? Retrieved from https://www.gasnetworks.ie/business/natural-gas-in-transport/transport-and-natural-gas/

IRENA. (2017). BIOGAS FOR ROAD VEHICLES TECHNOLOGY BRIEF (ISBN 978-92-9260-002-0). Retrieved from Abu Dhabi: http://www.irena.org/DocumentDownloads/Publications/IRENA Biogas for Road Vehicles 20 17.pdf

IRENA International Renewable Energy Agency, A. D. (2017). Biogas for Road Vehicles: Technology Brief. Retrieved from http://www.irena.org/DocumentDownloads/Publications/IRENA Biogas for Road Vehicles 20 17.pdf

ISO. (2006). ISO 14044:2006. Environmental management -- Life cycle assessment -- Requirements and guidelines. Retrieved from London: http://www.iso.org/iso/catalogue detail?csnumber $=38498$

Jin, Y., Li, Y., \& Li, J. (2016). Influence of thermal pretreatment on physical and chemical properties of kitchen waste and the efficiency of anaerobic digestion. Journal of Environmental Management, 180, 291-300. doi:https://doi.org/10.1016/i.jenvman.2016.05.047

Jury, C., Benetto, E., Koster, D., Schmitt, B., \& Welfring, J. (2010). Life Cycle Assessment of biogas production by monofermentation of energy crops and injection into the natural gas grid. Biomass and Bioenergy, 34(1), 54-66. doi:10.1016/j.biombioe.2009.09.011

Korres, E., Singh, A., Nizami, A., \& Murphy, J. (2010). Is grass biomethane a sustainable transport biofuel? Biofuels, Bioproducts and Biorefining, 4(3), 310-325. doi:doi:10.1002/bbb.228

KPMG. (2018). Decarbonising Domestic Heating in Ireland. Retrieved from Dublin: http://www.ervia.ie/decarbonising-domestic-he/KPMG-Irish-Gas-Pathways-Report.pdf

MacLean, H. L., \& Lave, L. B. (2003). Life Cycle Assessment of Automobile/Fuel Options. Environmental science \& technology, 37(23), 5445-5452. doi:10.1021/es034574q

Manfredi, S., Allacker, K., Chomkhamsri, K., Pelletier, N., \& de Souza, D. (2012). Product Environmental Footprint (PEF) Guide. Retrieved from Ispra, Italy: http://ec.europa.eu/environment/eussd/pdf/footprint/PEF\%20methodology\%20final\%20draft.p df

McKone, T. E., Nazaroff, W. W., Berck, P., Auffhammer, M., Lipman, T., Torn, M. S., ... Horvath, A. (2011). Grand Challenges for Life-Cycle Assessment of Biofuels. Environmental science \& technology, 45(5), 1751-1756. doi:10.1021/es103579c

McManus, M. C., \& Taylor, C. M. (2015). The changing nature of life cycle assessment. Biomass and Bioenergy, 82, 13-26. doi:https://doi.org/10.1016/j.biombioe.2015.04.024 
Murphy, F., Devlin, G., Deverell, R., \& McDonnell, K. (2014). Potential to increase indigenous biodiesel production to help meet 2020 targets - An EU perspective with a focus on Ireland. Renewable and Sustainable Energy Reviews, 35(0), 154-170. doi:http://dx.doi.org/10.1016/i.rser.2014.03.046

Nakatani, J. (2014). Life Cycle Inventory Analysis of Recycling: Mathematical and Graphical Frameworks. Sustainability, 6, 6158-6169;. doi:doi:10.3390/su6096158

Nations, U. (2015). Paris Agreement. Retrieved from Paris: https://unfccc.int/process-and-meetings/theparis-agreement/the-paris-agreement

Patterson, T., Esteves, S., Dinsdale, R., \& Guwy, A. (2011). An evaluation of the policy and techno-economic factors affecting the potential for biogas upgrading for transport fuel use in the UK. Energy Policy, 39(3), 1806-1816. doi:https://doi.org/10.1016/j.enpol.2011.01.017

Pehnt, M. (2006). Dynamic life cycle assessment (LCA) of renewable energy technologies. Renewable Energy, 31(1), 55-71. doi:https://doi.org/10.1016/j.renene.2005.03.002

Pelletier, N., Ardente, F., Brandão, M., De Camillis, C., \& Pennington, D. (2015). Rationales for and limitations of preferred solutions for multi-functionality problems in LCA: is increased consistency possible? The International Journal of Life Cycle Assessment, 20(1), 74-86. doi:10.1007/s11367014-0812-4

Pérez-Camacho, M. N., Curry, R., \& Cromie, T. (2017). Life cycle environmental impacts of substituting food wastes for traditional anaerobic digestion feedstocks. Waste Management, 73(March 2018), 140-155. doi:https://doi.org/10.1016/j.wasman.2017.12.023

Persson, M., Jonsson, O., \& Wellinger, A. (2006). Biogas Upgrading to Vehicle Fuel Standards and Grid Injection. Retrieved from http://task37.ieabioenergy.com/files/datenredaktion/download/publi-task37/upgrading report final.pdf

Pertl, A., Mostbauer, P., \& Obersteiner, G. (2010). Climate balance of biogas upgrading systems. Waste Manag, 30(1), 92-99. doi:10.1016/j.wasman.2009.08.011

Petersson, A., \& Wellinger, A. (2009). Biogas upgrading technologies-developments and innovations. Retrieved from https://www.infothekbiomasse.ch/images/175 2009 IEA Biogas upgrading technologies.pdf

Pöschl, M., Ward, S., \& Owende, P. (2010). Evaluation of energy efficiency of various biogas production and utilization pathways. Applied Energy, 87(11), 3305-3321. doi:http://dx.doi.org/10.1016/j.apenergy.2010.05.011

PRé, v. a. (2019). SimaPro Database Manual. Methods Library (4.14.2). Retrieved from Amersfoort, Netherlands: https://simapro.com/wp-content/uploads/2019/02/DatabaseManualMethods.pdf

Reap, J., Roman, F., Duncan, S., \& Bras, B. (2008). A survey of unresolved problems in life cycle assessment. The International Journal of Life Cycle Assessment, 13(4), 290. doi:10.1007/s11367-008-0008-x

Sala, S., Reale, F., Cristobal-Garcia, J., Marelli, L., \& Pant, R. (2016). Life cycle assessment for the impact assessment of policies. Retrieved from Brussels: https://ec.europa.eu/jrc/en/publication/lifecycle-assessment-impact-assessment-policies

Smyth, B. M., Smyth, H., \& Murphy, J. D. (2010). Can grass biomethane be an economically viable biofuel for the farmer and the consumer? Biofuels, Bioproducts and Biorefining, 4(5), 519-537. doi:10.1002/bbb.238

Starr, K., Villalba, G., \& Gabarrell, X. (2015). Upgraded biogas from municipal solid waste for natural gas substitution and $\mathrm{CO} 2$ reduction - A case study of Austria, Italy, and Spain. Waste Management, 38, 105-116. doi:https://doi.org/10.1016/j.wasman.2015.01.001

Stephenson, A., Kazamia, E., Dennis, J., Howe, C., Scott, S., \& Smith, A. (2010). Life-Cycle Assessment of Potential Algal Biodiesel Production in the United Kingdom: A Comparison of Raceways and AirLift Tubular Bioreactors. Energy Fuels, 24. 
680
Styles, D., Dominguez, E. M., \& Chadwick, D. (2016). Environmental balance of the UK biogas sector: An evaluation by consequential life cycle assessment. Science of The Total Environment, 560561(Supplement C), 241-253. doi:https://doi.org/10.1016/j.scitotenv.2016.03.236

Woon, K., Lo, I., Chiu, S., \& Yan, D. (2016). Environmental assessment of food waste valorization in producing biogas for various types of energy use based on LCA approach. Waste Management, 50(Supplement C), 290-299. doi:https://doi.org/10.1016/j.wasman.2016.02.022

Woon, K. S., Lo, I. M., Chiu, S. L., \& Yan, D. Y. (2016). Environmental assessment of food waste valorization in producing biogas for various types of energy use based on LCA approach. Waste Manag, 50, 290-299. doi:10.1016/j.wasman.2016.02.022

Zhen, G., Lu, X., Kato, H., Zhao, Y., \& Li, Y.-Y. (2017). Overview of pretreatment strategies for enhancing sewage sludge disintegration and subsequent anaerobic digestion: Current advances, full-scale application and future perspectives. Renewable and Sustainable Energy Reviews, 69, 559-577. doi:https://doi.org/10.1016/j.rser.2016.11.187 


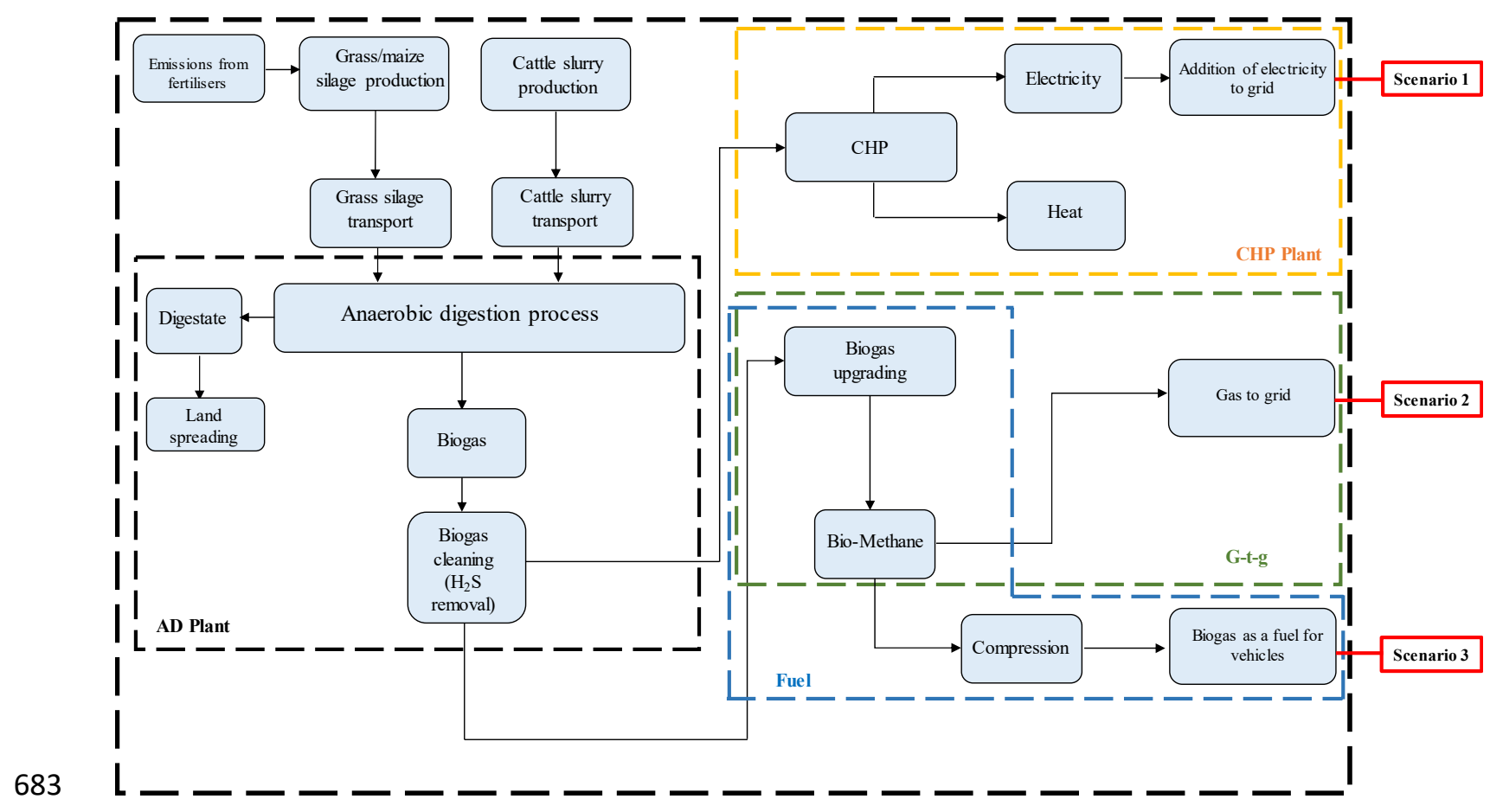

684 Figure 1. System boundaries for the three main scenarios considered. Scenario 1: biogas utilisation in a 685 CHP plant for electricity and heat production. Scenario 2: Gas to grid for heating. Scenario 3: Biogas as a 686 fuel for vehicles. 


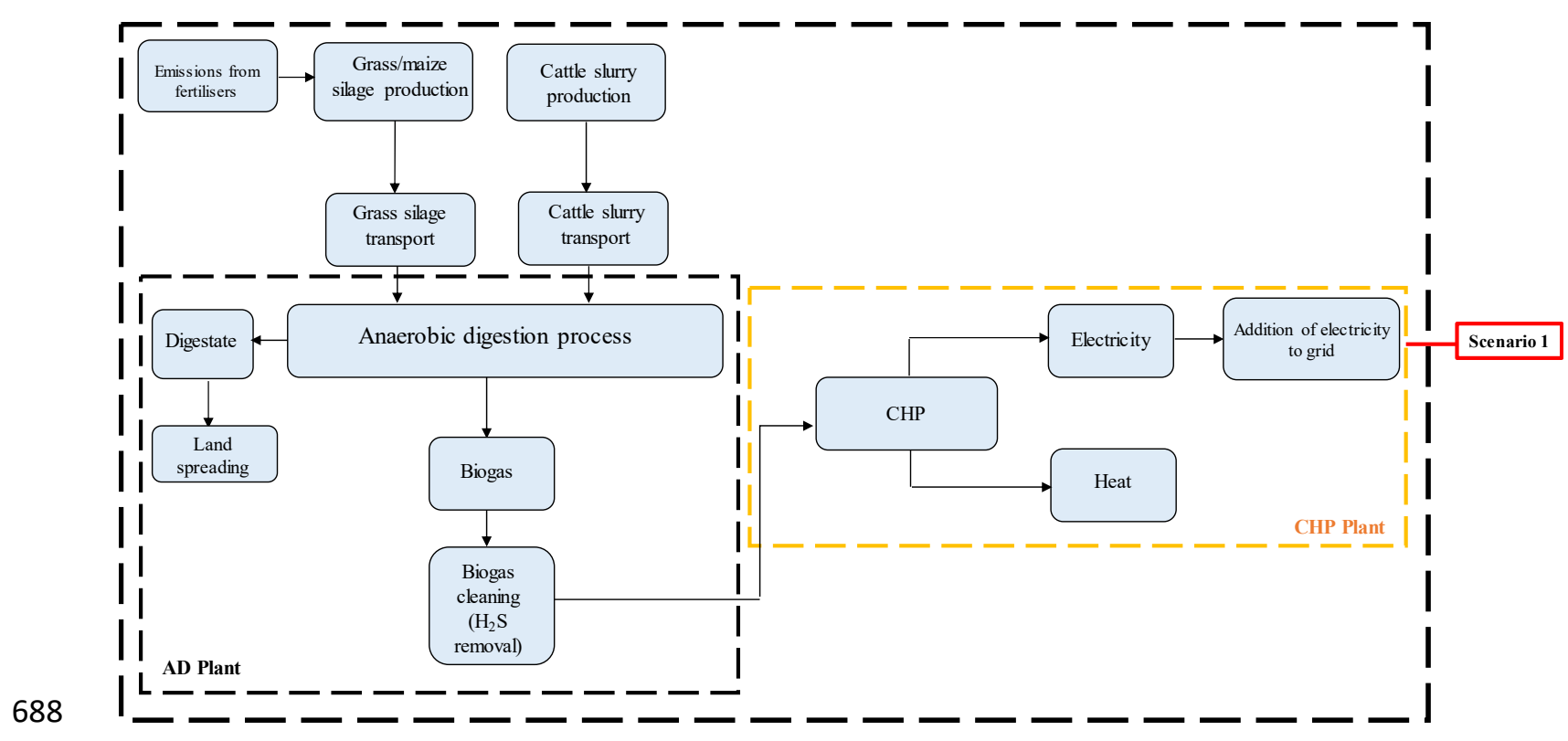

689 Figure 2. System boundaries for scenario 1: biogas utilisation in a CHP plant for electricity and heat 690 production. 


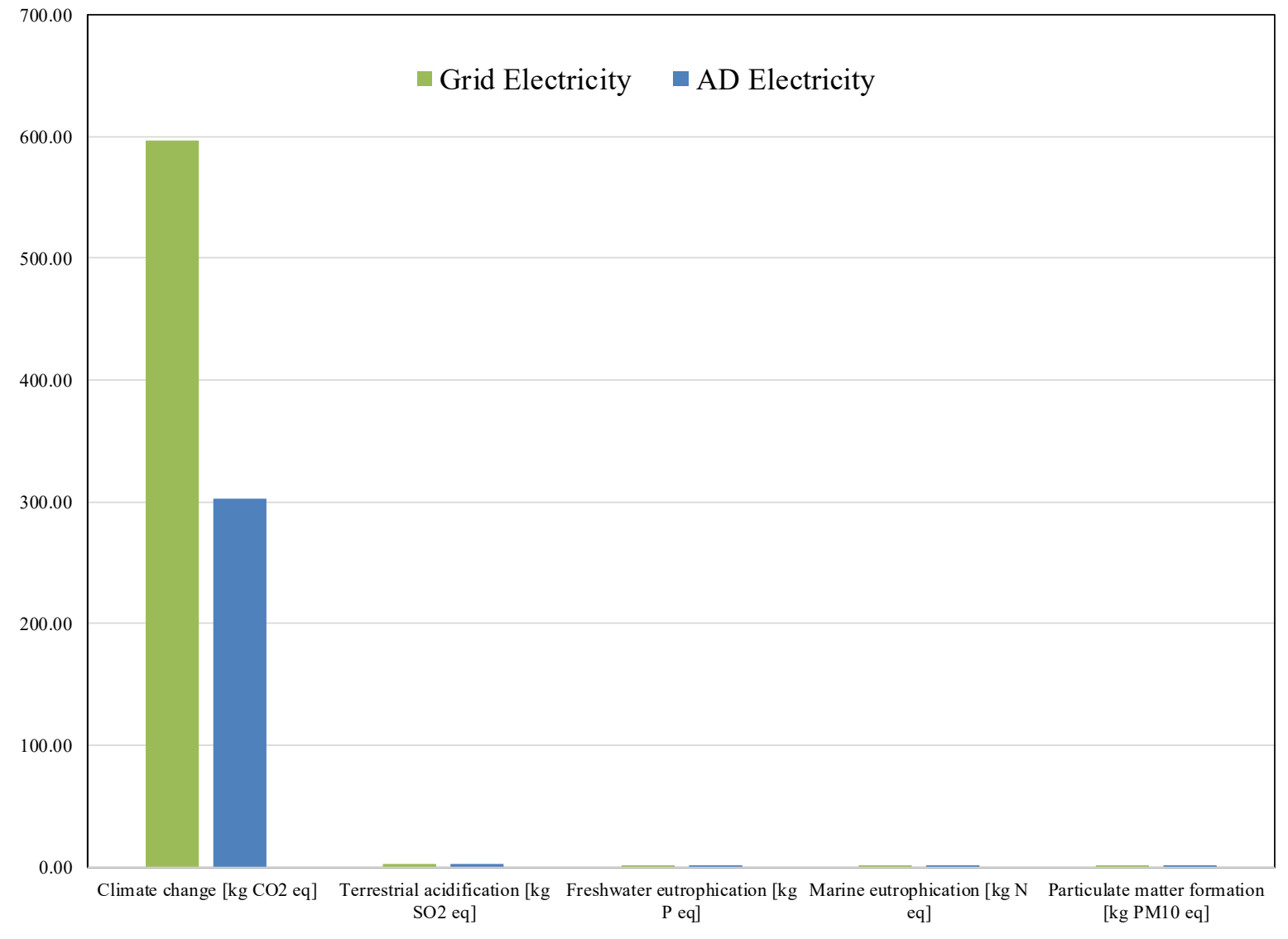

693 Figure 3. Environmental impacts of $1 \mathrm{MWh}$ of electricity production into the grid from NI grid ( $\square$ ) and AD 694 of maize/grass silage and cattle slurry ( $\square)$. 


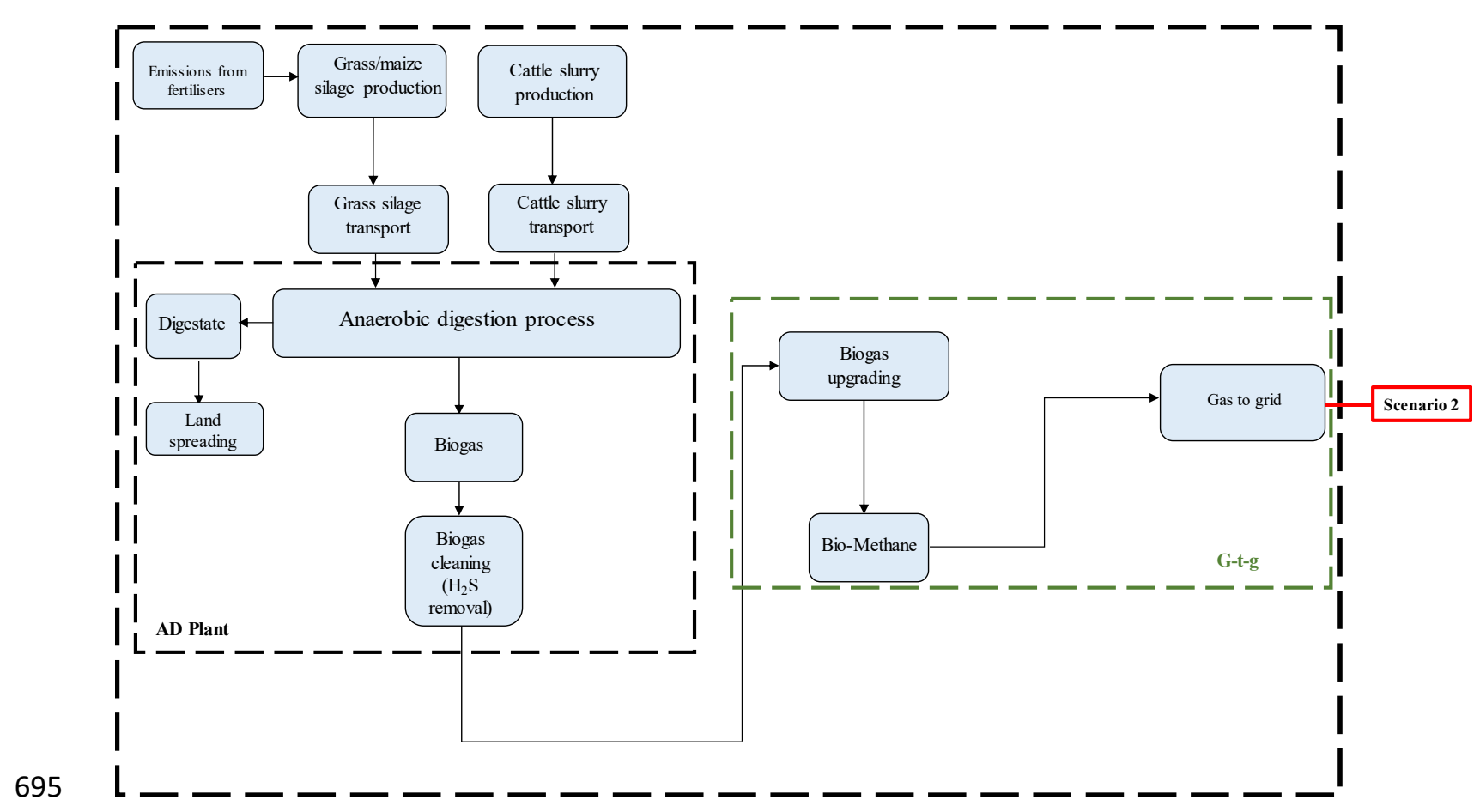

696 Figure 4. System boundaries for scenario 2: gas to grid. 


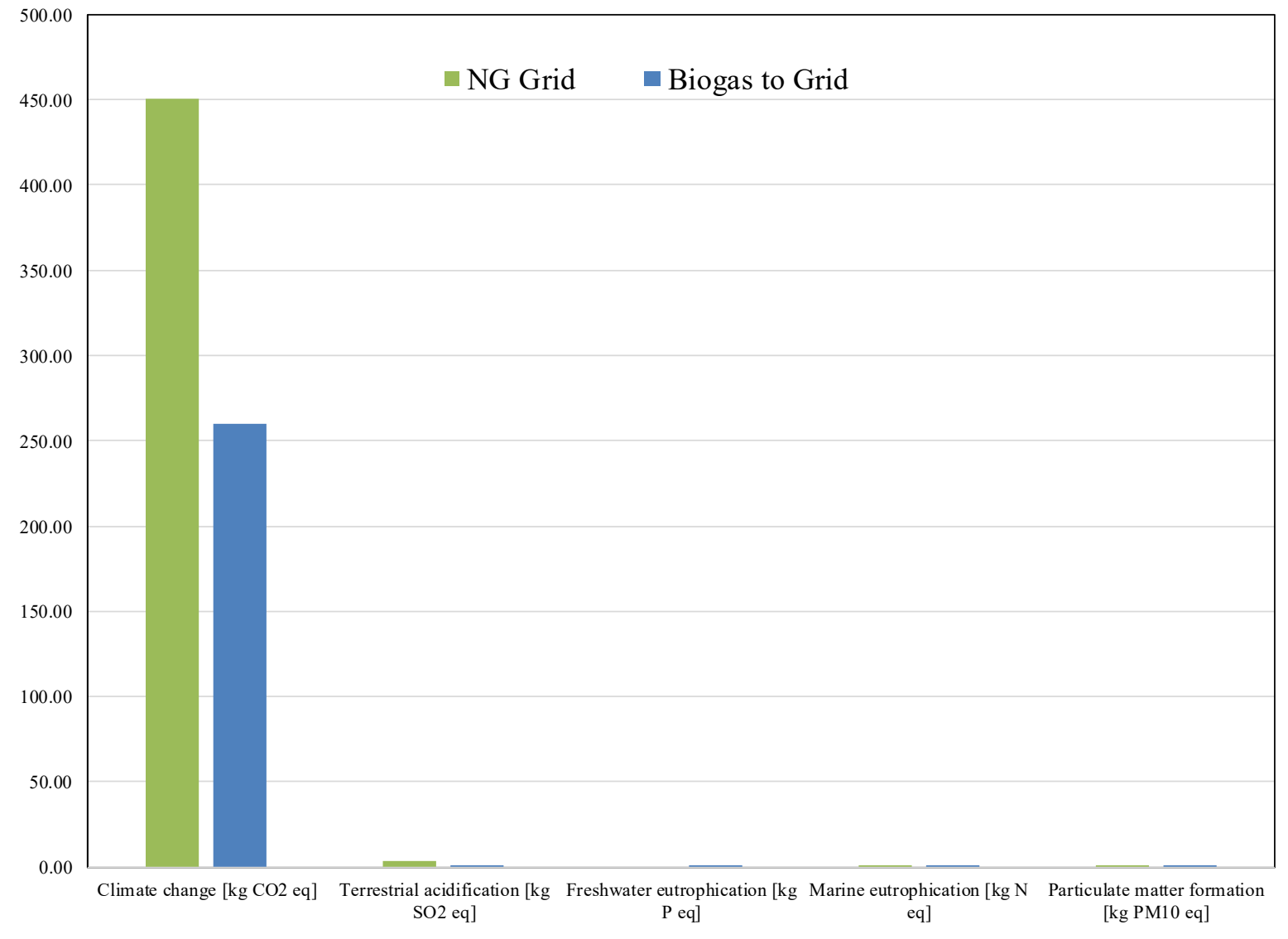

698 Figure 5. Environmental impacts of $1 \mathrm{MWh}$ of gas production into the grid from natural gas grid ( $\square)$ and biogas to grid ( $\square$ ). 


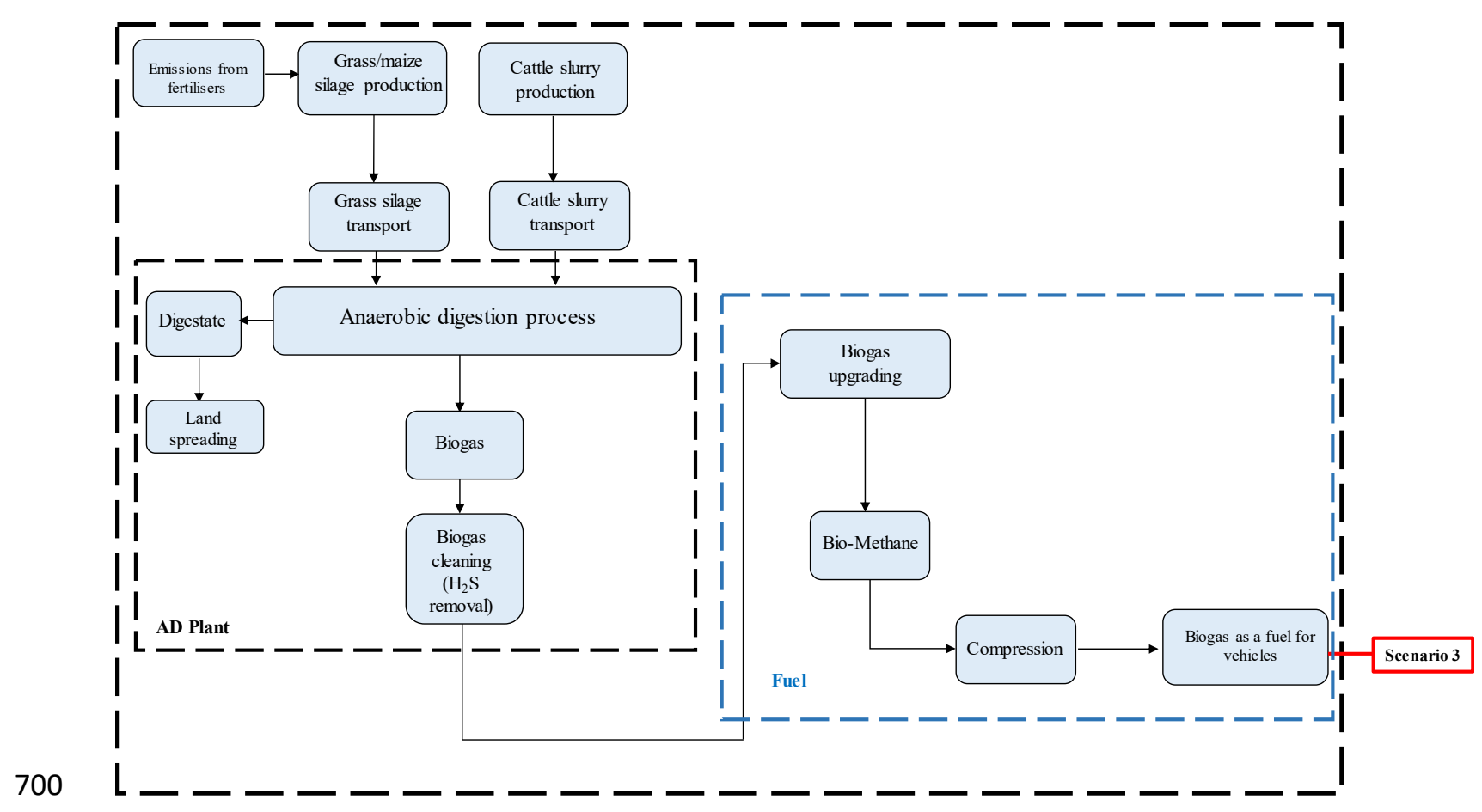

701 Figure 6. System boundaries for the scenario 3: biogas as a fuel for vehicles. 


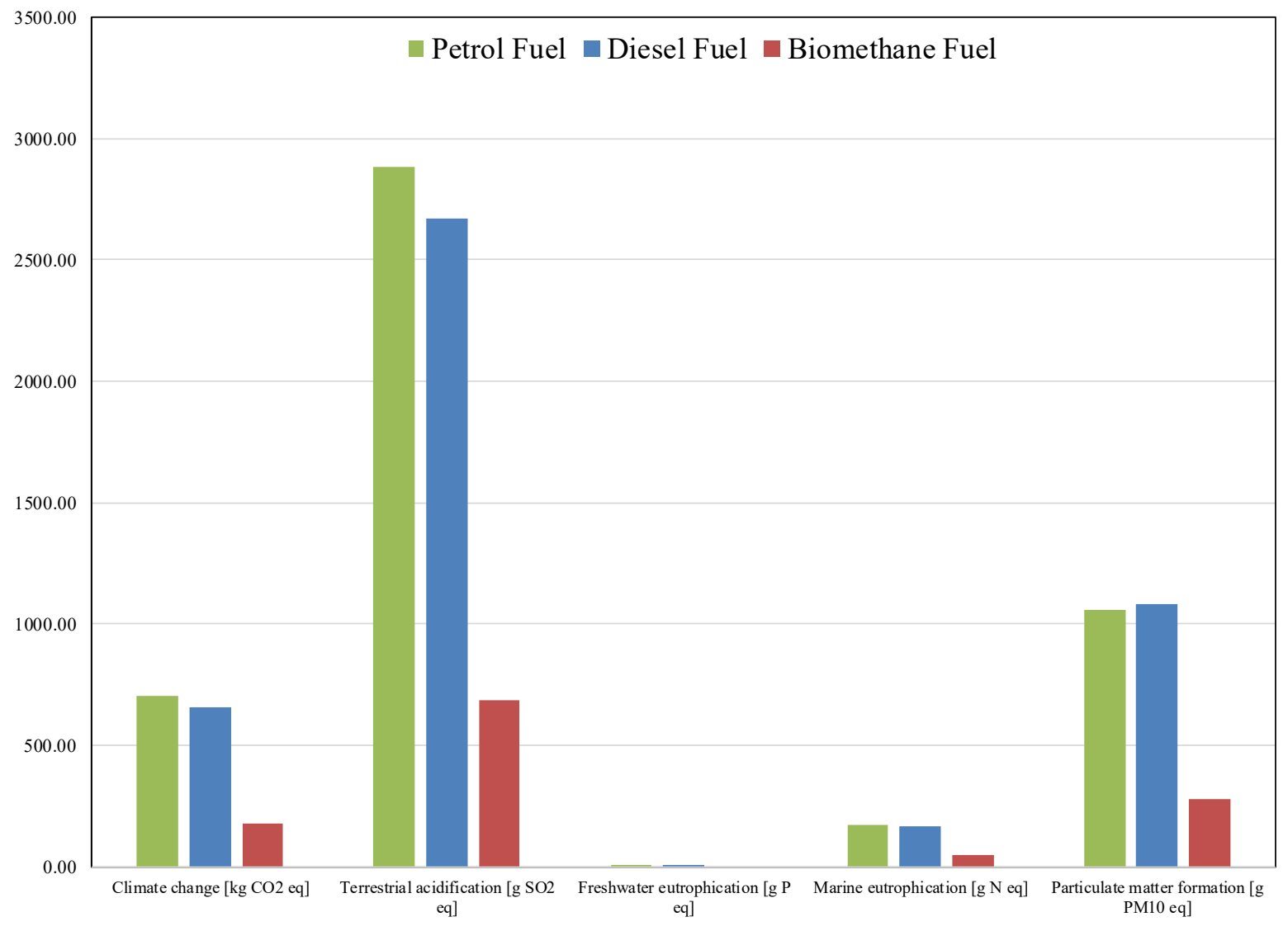

703 Figure 7. Environmental Impacts of $1 \mathrm{MWh}$ of utilization of different fuels for vehicles: petrol ( $\square$ ); diesel $(\square)$; and biomethane ( $\square$ ). 


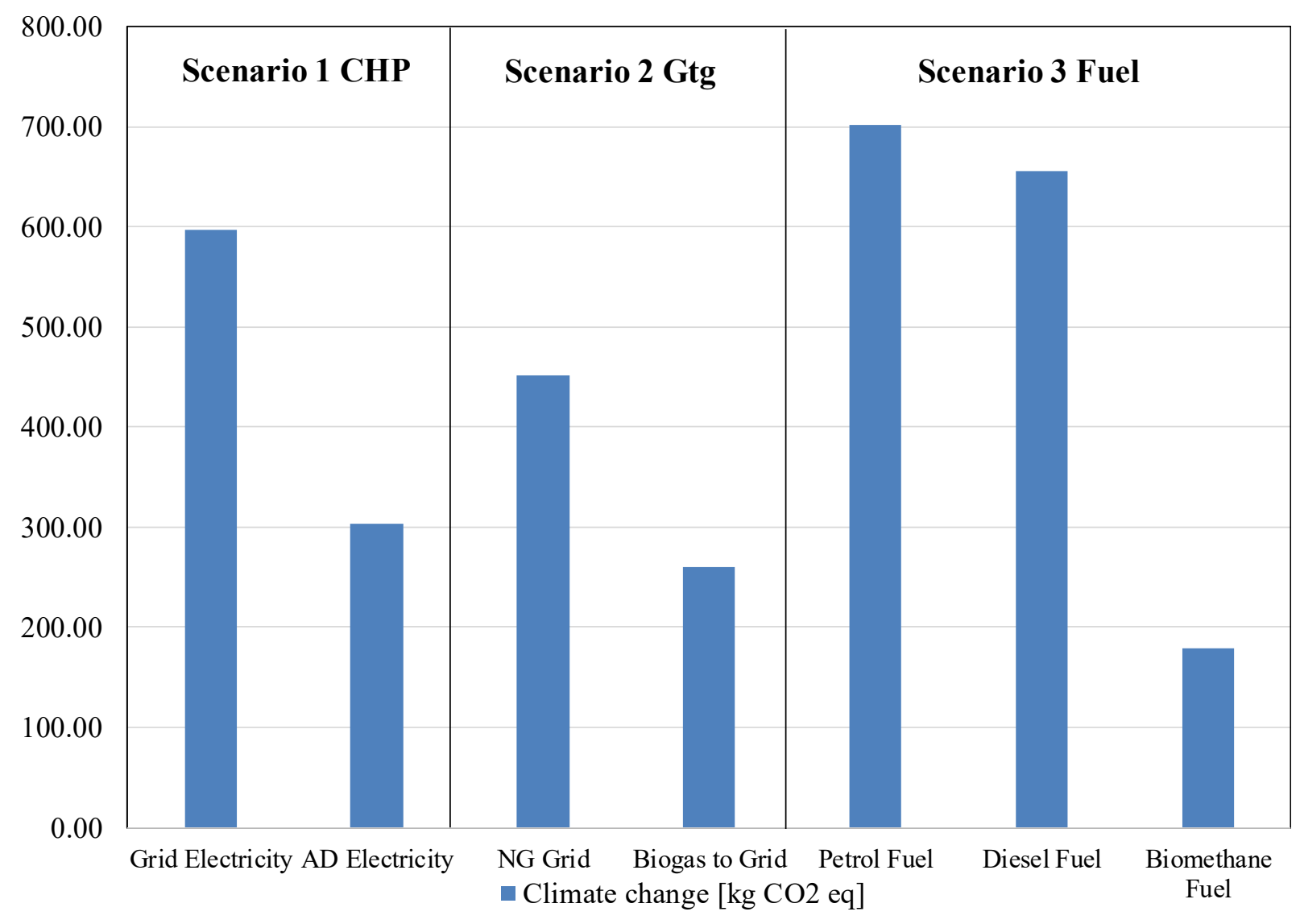

706 Figure 8. Summary GWP for the 3 scenarios considered. 


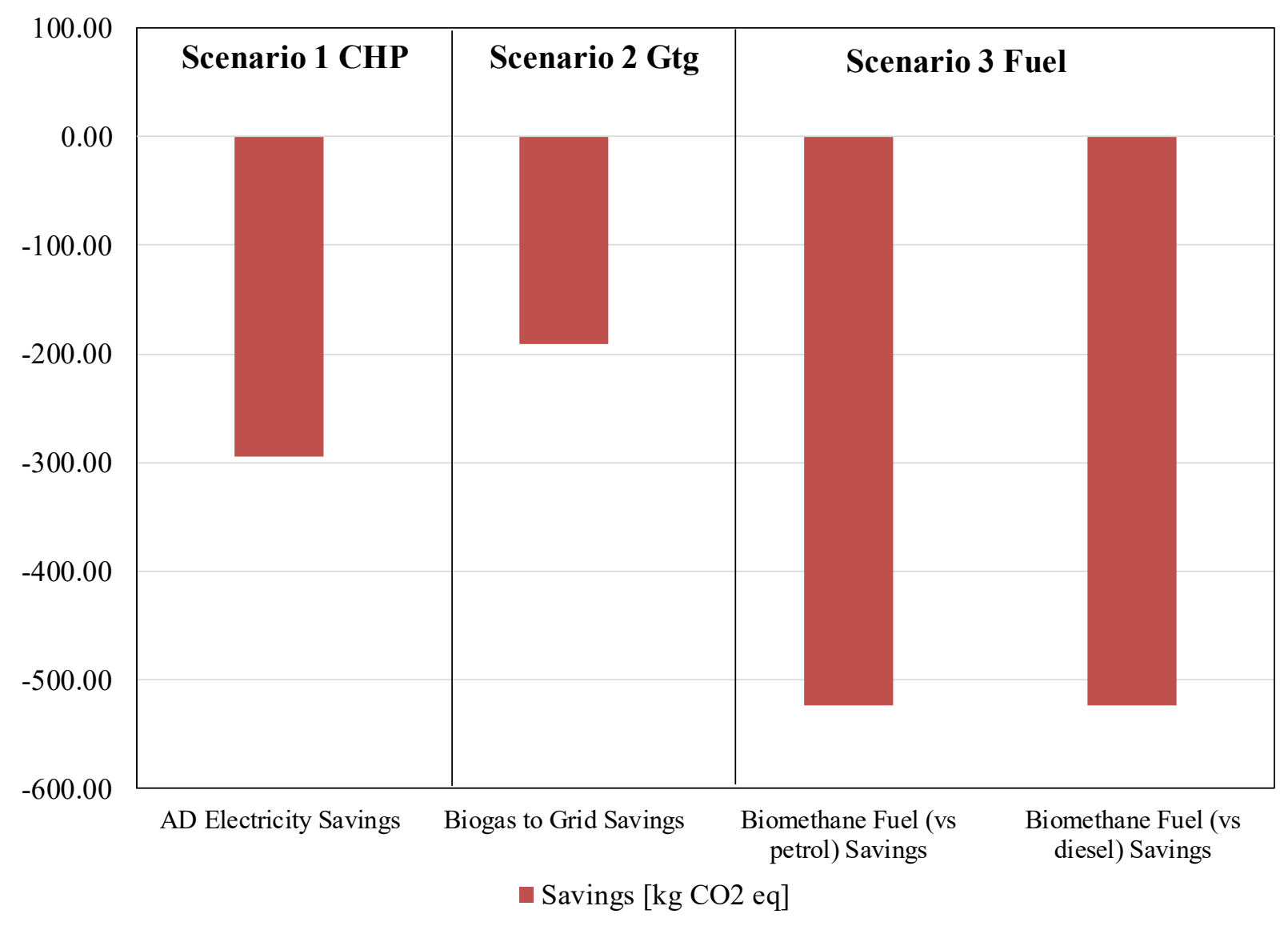

708 Figure 9. Summary of $\mathrm{CO}_{2}$ emission savings for the 3 scenarios considered. 


\section{Supplementary Information (SI). Tables and Data Inventory.}

\section{Tables}

Table 1. Summary of data and data sources for modelling scenarios 1, 2 and 3.

\begin{tabular}{|c|c|c|}
\hline Data & Amount & Source \\
\hline \multicolumn{3}{|l|}{ Inputs to $\mathrm{AD}$ plant } \\
\hline Cattle slurry & 26.4 tonne per day & AD plant owner \\
\hline Maize/Grass silage & 19.8 tonne per day & AD plant owner \\
\hline Heat (from CHP) & $3017 \mathrm{kWh}$ per day & AD plant designer \\
\hline Electricity (from CHP) & $2320 \mathrm{kWh}$ per day & AD plant owner \\
\hline \multicolumn{3}{|l|}{ Outputs from AD plant/CHP plant } \\
\hline Biogas & $3498 \mathrm{~m}^{3} /$ day & AD plant owner \\
\hline Digestate & $5494.4 \mathrm{~m}^{3}$ over 3.5 months & AD plant owner \\
\hline \multicolumn{3}{|l|}{ Option 1: CHP/ AD Electricity } \\
\hline Electricity total & $8880 \mathrm{kWh}$ per day & AD plant owner \\
\hline Electricity to grid & $6560 \mathrm{kWh}$ per day & AD plant owner \\
\hline Heat & $9052 \mathrm{kWh}$ per day & AD plant owner \\
\hline \multicolumn{3}{|l|}{ Option 2: Biogas to NG Grid } \\
\hline Biomethane & $1755.16 \mathrm{~m}^{3}(17200 \mathrm{kWh}$ per day $)$ & AD plant owner \\
\hline Mix of gases & $1742.84 \mathrm{~m}^{3}$ & AD plant owner \\
\hline Electricity used (upgrading) & $705.1 \mathrm{kWh}$ per day & (1) \\
\hline \multicolumn{3}{|l|}{ Option 3: Biogas as a Vehicle Fuel } \\
\hline Biomethane & $1755.16 \mathrm{~m}^{3}(17200 \mathrm{kWh}$ per day) & AD plant owner \\
\hline Mix of gases & $1742.84 \mathrm{~m}^{3}$ & AD plant owner \\
\hline $\begin{array}{l}\text { Electricity used (upgrading plus } \\
\text { compression) }\end{array}$ & $1316.37 \mathrm{kWh}$ & (2) \\
\hline
\end{tabular}

(1)(Patterson et al., 2011) (2)(Patterson et al., 2011), (Smyth et al., 2010). 
Table 2. Environmental impacts of $1 \mathrm{MWh}$ of electricity production into the grid for scenario 1 using grid electricity and $\mathrm{AD}$ electricity.

\begin{tabular}{|l|l|l|l|l|l|}
\hline No. & Impact category & Unit & $(\mathrm{a}) \mathrm{NI}$ Grid & $(\mathrm{b}) \mathrm{GS}+\mathrm{CS}$ & Savings \\
\hline 1 & Climate change & $\mathrm{kg} \mathrm{CO}$ eq & 597.11 & 302.77 & -294.34 \\
\hline 2 & Ozone depletion & $\mathrm{kg} \mathrm{CFC-11} \mathrm{eq}$ & 0.00001 & 0.00033 & 0.00032 \\
\hline 3 & Terrestrial acidification & $\mathrm{kg} \mathrm{SO}$ eq & 2.75 & 2.54 & -0.21 \\
\hline 4 & Freshwater eutrophication & $\mathrm{kg} \mathrm{P}$ eq & 0.19 & 0.11 & -0.08 \\
\hline 5 & Marine eutrophication & $\mathrm{kg} \mathrm{N}$ eq & 0.09 & 0.35 & 0.26 \\
\hline 6 & Human toxicity & $\mathrm{kg} 1,4-\mathrm{DCB}$ eq & 123.73 & 106.12 & -17.61 \\
\hline 7 & Photochemical oxidant formation & $\mathrm{kg} \mathrm{NMVOC}$ & 1.23 & 1.52 & 0.29 \\
\hline 8 & Particulate matter formation & $\mathrm{kg} \mathrm{PM10} \mathrm{eq}$ & 0.80 & 1.00 & 0.20 \\
\hline 9 & Terrestrial ecotoxicity & $\mathrm{kg} 1,4-\mathrm{DCB}$ eq & 0.01 & 0.13 & 0.11 \\
\hline 10 & Freshwater ecotoxicity & $\mathrm{kg} 1,4-\mathrm{DCB}$ eq & 3.40 & 2.63 & -0.77 \\
\hline 11 & Marine ecotoxicity & $\mathrm{kg} 1,4-\mathrm{DCB}$ eq & 3.39 & 2.44 & -0.95 \\
\hline 12 & Ionising radiation & $\mathrm{kBq}$ U235 eq & 35.71 & 40.80 & 5.09 \\
\hline 13 & Agricultural land occupation & $\mathrm{m}{ }^{2} \mathrm{a}$ & 55.97 & 1094.75 & 1038.79 \\
\hline 14 & Urban land occupation & $\mathrm{m}{ }^{2} \mathrm{a}$ & 4.56 & 2.80 & -1.77 \\
\hline 15 & Natural land transformation & $\mathrm{m}{ }^{2}$ & 0.09 & 0.17 & 0.08 \\
\hline 16 & Water depletion & $\mathrm{m}{ }^{3}$ & 1.47 & 1.97 & 0.50 \\
\hline 17 & Metal depletion & $\mathrm{kg} \mathrm{Fe} \mathrm{eq}$ & 4.79 & 19.64 & 14.85 \\
\hline 18 & Fossil fuel depletion & 158.06 & 190.24 & 32.18 \\
\hline
\end{tabular}


Table 3. Environmental impacts of $1 \mathrm{MWh}$ of NG/biomethane production into the gas grid for scenario

2.

\begin{tabular}{|c|c|c|c|c|}
\hline No. & Impact category & NG Grid & Biogas to Grid & Savings \\
\hline 1 & Climate change $\left[\mathrm{kg} \mathrm{CO}_{2} \mathrm{eq}\right]$ & 450.71 & 259.67 & -191.04 \\
\hline 2 & Ozone depletion [kg CFC-11 eq] & 0.00000 & 0.00016 & 0.00016 \\
\hline 3 & Terrestrial acidification $\left[\mathrm{kg} \mathrm{SO}_{2} \mathrm{eq}\right]$ & 3.80 & 1.14 & -2.66 \\
\hline 4 & Freshwater eutrophication [kg P eq] & 0.00 & 0.05 & 0.05 \\
\hline 5 & Marine eutrophication [kg N eq] & 0.02 & 0.16 & 0.14 \\
\hline 6 & Human toxicity [kg 1,4-DCB eq] & 82.68 & 49.97 & -32.72 \\
\hline 7 & Photochemical oxidant formation [kg NMVOC] & 0.71 & 0.69 & -0.02 \\
\hline 8 & Particulate matter formation [kg PM10 eq] & 0.83 & 0.45 & -0.37 \\
\hline 9 & Terrestrial ecotoxicity [kg 1,4-DCB eq] & 0.00 & 0.06 & 0.06 \\
\hline 10 & Freshwater ecotoxicity [kg 1,4-DCB eq] & 1.09 & 1.24 & 0.15 \\
\hline 11 & Marine ecotoxicity [kg 1,4-DCB eq] & 1.00 & 1.15 & 0.15 \\
\hline 12 & Ionising radiation $[\mathrm{kBq} \mathrm{U} 235 \mathrm{eq}]$ & 0.00 & 18.95 & 18.95 \\
\hline 13 & Agricultural land occupation $\left[\mathrm{m}^{2} \mathrm{a}\right]$ & 0.00 & 515.93 & 515.93 \\
\hline 14 & Urban land occupation $\left[\mathrm{m}^{2} \mathrm{a}\right]$ & 0.00 & 1.32 & 1.32 \\
\hline 15 & Natural land transformation $\left[\mathrm{m}^{2}\right]$ & 0.00 & 0.08 & 0.08 \\
\hline 16 & Water depletion $\left[\mathrm{m}^{3}\right]$ & 0.00 & 0.91 & 0.91 \\
\hline 17 & Metal depletion [kg Fe eq] & 0.00 & 9.26 & 9.26 \\
\hline 18 & Fossil fuel depletion [kg oil eq] & 170.82 & 87.21 & -83.62 \\
\hline
\end{tabular}


Table 4. Environmental impacts of $1 \mathrm{MWh}$ of petrol/diesel/biomethane fuel for scenario 3.

\begin{tabular}{|c|c|c|c|c|c|c|}
\hline No. & Impact category & Petrol Fuel & Diesel Fuel & $\begin{array}{c}\text { Biomethane } \\
\text { Fuel }\end{array}$ & $\begin{array}{c}\text { Savings } \\
\text { respect } \\
\text { petrol }\end{array}$ & $\begin{array}{l}\text { Savings } \\
\text { respect } \\
\text { diesel }\end{array}$ \\
\hline 1 & Climate change $\left[\mathrm{kg} \mathrm{CO}_{2} \mathrm{eq}\right]$ & 701.82 & 654.91 & 178.35 & -523.48 & -476.56 \\
\hline 2 & Ozone depletion [kg CFC-11 eq] & $1.72 \mathrm{E}-06$ & $1.34 \mathrm{E}-06$ & $0.00 \mathrm{E}+00$ & $-1.72 \mathrm{E}-06$ & $-1.34 \mathrm{E}-06$ \\
\hline 3 & Terrestrial acidification $\left[\mathrm{kg} \mathrm{SO}_{2} \mathrm{eq}\right]$ & 2.88 & 2.67 & 0.69 & -2.19 & -1.98 \\
\hline 4 & Freshwater eutrophication [kg P eq] & 0.00 & 0.00 & 0.00 & 0.00 & 0.00 \\
\hline 5 & Marine eutrophication [ $\mathrm{kg} \mathrm{N} \mathrm{eq]}$ & 0.17 & 0.17 & 0.05 & -0.12 & -0.12 \\
\hline 6 & Human toxicity [kg 1,4-DCB eq] & 11.83 & 9.60 & 2.20 & -9.63 & -7.40 \\
\hline 7 & Photochemical oxidant formation [kg NMVOC] & 4.56 & 4.43 & 1.27 & -3.29 & -3.16 \\
\hline 8 & Particulate matter formation [kg PM10 eq] & 1.06 & 1.08 & 0.28 & -0.78 & -0.80 \\
\hline 9 & Terrestrial ecotoxicity [kg 1,4-DCB eq] & 0.04 & 0.04 & 0.01 & -0.03 & -0.03 \\
\hline 10 & Freshwater ecotoxicity [kg 1,4-DCB eq] & 0.05 & 0.04 & 0.01 & -0.04 & -0.04 \\
\hline 11 & Marine ecotoxicity [kg 1,4-DCB eq] & 0.42 & 0.40 & 0.06 & -0.36 & -0.33 \\
\hline 12 & Ionising radiation [kBq $\mathrm{U} 235 \mathrm{eq}]$ & 2.09 & 1.63 & 0.00 & -2.09 & -1.63 \\
\hline 13 & Agricultural land occupation $\left[\mathrm{m}^{2} \mathrm{a}\right]$ & $2.12 \mathrm{E}-03$ & $2.11 \mathrm{E}-03$ & $0.00 \mathrm{E}+00$ & $-2.12 \mathrm{E}-03$ & $-2.11 \mathrm{E}-03$ \\
\hline 14 & Urban land occupation $\left[\mathrm{m}^{2} \mathrm{a}\right]$ & 0.00 & 0.00 & 0.00 & 0.00 & 0.00 \\
\hline 15 & Natural land transformation $\left[\mathrm{m}^{2}\right]$ & 0.00 & 0.00 & 0.00 & 0.00 & 0.00 \\
\hline 16 & Water depletion $\left[\mathrm{m}^{3}\right]$ & 0.01 & 0.06 & 0.00 & -0.01 & -0.06 \\
\hline 17 & Metal depletion [kg Fe eq] & 0.15 & 0.16 & 0.00 & -0.15 & -0.16 \\
\hline 18 & Fossil fuel depletion [kg oil eq] & 201.76 & 210.24 & 0.00 & -201.76 & -210.24 \\
\hline
\end{tabular}


Table 5. Summary of upgrading technologies energy requirements and data for sensitivity analysis calculations.

\begin{tabular}{|c|c|c|c|c|}
\hline $\begin{array}{l}\text { Scen } \\
\text { ario }\end{array}$ & Upgrading technology & $\begin{array}{l}\text { Electricity used }\left(\mathrm{KWh} / \mathrm{m}^{3}\right. \\
\text { of biomethane })^{1}\end{array}$ & $\begin{array}{l}\text { Total electricity } \\
\text { consumed (kWh/day) }\end{array}$ & $\begin{array}{l}\text { Electricity left for grid } \\
\text { injection }(\mathrm{kWh} / \text { day })\end{array}$ \\
\hline 1 & $\begin{array}{l}\text { PSA (Pressure Swing } \\
\text { Adsorption) }\end{array}$ & 0.41 & 723.1 & 5836.9 \\
\hline 2 & Water scrubbing & 0.39 & 700.7 & 5859.3 \\
\hline 3 & $\begin{array}{l}\text { Organic physical } \\
\text { scrubbing }\end{array}$ & 0.47 & 819.7 & 5740.3 \\
\hline 4 & Chemical scrubbing & 0.26 & 457.2 & 6102.8 \\
\hline 5 & Cryogenic separation & 0.42 & 737.2 & 5822.8 \\
\hline $\begin{array}{l}\text { Basel } \\
\text { ine }\end{array}$ & $\begin{array}{l}\text { Membrane separation } \\
\text { (baseline) }\end{array}$ & 0.40 & 705.1 & 5854.9 \\
\hline
\end{tabular}


Table 6. Sensitivity analysis LCA results for the different biogas upgrading technologies considered.

\begin{tabular}{|c|c|c|c|c|c|c|c|}
\hline No. & $\begin{array}{l}\text { Impact } \\
\text { category }\end{array}$ & (1) PSA & $\begin{array}{l}\text { (2) Water } \\
\text { scrubbing }\end{array}$ & $\begin{array}{c}\text { (3) Organic } \\
\text { physical scrubbing }\end{array}$ & $\begin{array}{l}\text { (4) Chemical } \\
\text { scrubbing }\end{array}$ & $\begin{array}{c}\text { (5) } \\
\text { Cryogenic } \\
\text { separation }\end{array}$ & $\begin{array}{l}\text { Membrane } \\
\text { separation } \\
\text { (baseline) }\end{array}$ \\
\hline 1 & $\begin{array}{c}\text { Climate change } \\
\left.\qquad \mathrm{kg} \mathrm{CO}_{2} \text { eq }\right]\end{array}$ & 259.97 & 259.67 & 261.59 & 255.51 & 260.21 & 259.67 \\
\hline 2 & $\begin{array}{c}\text { Ozone } \\
\text { depletion }[\mathrm{kg} \\
\text { CFC-11 eq] }\end{array}$ & 0.000156 & 0.000155 & 0.000157 & 0.000151 & 0.000156 & 0.000155 \\
\hline 3 & $\begin{array}{c}\text { Terrestrial } \\
\text { acidification } \\
{\left[\mathrm{kg} \mathrm{SO}_{2} \text { eq] }\right.}\end{array}$ & 1.15 & 1.14 & 1.16 & 1.11 & 1.15 & 1.14 \\
\hline 4 & $\begin{array}{c}\text { Freshwater } \\
\text { eutrophication } \\
\text { [kg P eq }]\end{array}$ & 0.05 & 0.05 & 0.05 & 0.05 & 0.05 & 0.05 \\
\hline 5 & $\begin{array}{c}\text { Marine } \\
\text { eutrophication } \\
{[\mathrm{kg} \mathrm{N} \mathrm{eq]}}\end{array}$ & 0.16 & 0.16 & 0.16 & 0.16 & 0.16 & 0.16 \\
\hline 6 & $\begin{array}{l}\text { Human toxicity } \\
\text { [kg 1,4-DCB } \\
\text { eq }]\end{array}$ & 50.07 & 49.97 & 50.64 & 48.51 & 50.16 & 49.97 \\
\hline 7 & $\begin{array}{c}\text { Photochemical } \\
\text { oxidant } \\
\text { formation [kg } \\
\text { NMVOC] }\end{array}$ & 0.69 & 0.69 & 0.69 & 0.66 & 0.69 & 0.69 \\
\hline 8 & $\begin{array}{c}\text { Particulate } \\
\text { matter } \\
\text { formation [kg } \\
\text { PM10 eq] }\end{array}$ & 0.45 & 0.45 & 0.46 & 0.44 & 0.45 & 0.45 \\
\hline
\end{tabular}




\begin{tabular}{|c|c|c|c|c|c|c|c|}
\hline No. & $\begin{array}{l}\text { Impact } \\
\text { category }\end{array}$ & (1) PSA & $\begin{array}{l}\text { (2) Water } \\
\text { scrubbing }\end{array}$ & $\begin{array}{c}\text { (3) Organic } \\
\text { physical scrubbing }\end{array}$ & $\begin{array}{l}\text { (4) Chemical } \\
\text { scrubbing }\end{array}$ & $\begin{array}{c}\text { (5) } \\
\text { Cryogenic } \\
\text { separation }\end{array}$ & $\begin{array}{l}\text { Membrane } \\
\text { separation } \\
\text { (baseline) }\end{array}$ \\
\hline 9 & $\begin{array}{c}\text { Terrestrial } \\
\text { ecotoxicity [kg } \\
\text { 1,4-DCB eq] }\end{array}$ & 0.06 & 0.06 & 0.06 & 0.06 & 0.06 & 0.06 \\
\hline 10 & $\begin{array}{c}\text { Freshwater } \\
\text { ecotoxicity [kg } \\
\text { 1,4-DCB eq] }\end{array}$ & 1.24 & 1.24 & 1.26 & 1.21 & 1.25 & 1.24 \\
\hline 11 & $\begin{array}{c}\text { Marine } \\
\text { ecotoxicity }[\mathrm{kg} \\
\text { 1,4-DCB eq] }\end{array}$ & 1.15 & 1.15 & 1.16 & 1.11 & 1.15 & 1.15 \\
\hline 12 & $\begin{array}{c}\text { Ionising } \\
\text { radiation }[\mathrm{kBq} \\
\mathrm{U} 235 \mathrm{eq}]\end{array}$ & 18.99 & 18.95 & 19.21 & 18.39 & 19.02 & 18.95 \\
\hline 13 & $\begin{array}{c}\text { Agricultural } \\
\text { land occupation } \\
\qquad\left[\mathrm{m}^{2} \mathrm{a}\right]\end{array}$ & 517.02 & 515.93 & 522.88 & 500.90 & 517.88 & 515.93 \\
\hline 14 & $\begin{array}{c}\text { Urban land } \\
\text { occupation } \\
{\left[\mathrm{m}^{2} \mathrm{a}\right]}\end{array}$ & 1.31 & 1.31 & 1.34 & 1.28 & 1.32 & 1.32 \\
\hline 15 & $\begin{array}{c}\text { Natural land } \\
\text { transformation } \\
{\left[\mathrm{m}^{2}\right]}\end{array}$ & 0.08 & 0.08 & 0.08 & 0.08 & 0.08 & 0.08 \\
\hline 16 & $\begin{array}{c}\text { Water } \\
\text { depletion }\left[\mathrm{m}^{3}\right]\end{array}$ & 0.91 & 0.91 & 0.93 & 0.89 & 0.92 & 0.91 \\
\hline 17 & $\begin{array}{c}\text { Metal depletion } \\
\qquad \mathrm{kg} \mathrm{Fe} \mathrm{eq]}\end{array}$ & 9.19 & 9.21 & 9.38 & 8.99 & 9.29 & 9.26 \\
\hline 18 & $\begin{array}{c}\text { Fossil fuel } \\
\text { depletion [kg } \\
\text { oil eq] }\end{array}$ & 86.53 & 86.76 & 88.41 & 84.60 & 87.54 & 87.21 \\
\hline
\end{tabular}


Table 7. Sensitivity analysis LCA results for the different fuel rates considered in the dual fuel vehicle.

\begin{tabular}{|c|c|c|c|c|c|c|}
\hline No. & Impact category & $\begin{array}{l}\text { BioM: } \\
\text { Diesel } \\
\text { 100:0 }\end{array}$ & $\begin{array}{l}\text { BioM: } \\
\text { Diesel } \\
70: 30\end{array}$ & $\begin{array}{l}\text { BioM: } \\
\text { Diesel } \\
50: 50\end{array}$ & $\begin{array}{l}\text { BioM: Diesel } \\
\text { 30:70 }\end{array}$ & $\begin{array}{l}\text { BioM: Diesel } \\
\text { 0:100 }\end{array}$ \\
\hline 1 & Climate change $\left[\mathrm{kg} \mathrm{CO}_{2} \mathrm{eq}\right]$ & 178.35 & 318.87 & 414.88 & 510.89 & 654.91 \\
\hline 2 & Ozone depletion [kg CFC-11 eq] & $0.00 \mathrm{E}+00$ & $4.02 \mathrm{E}-07$ & $6.70 \mathrm{E}-07$ & 9.37E-07 & 1.34E-06 \\
\hline 3 & Terrestrial acidification $\left[\mathrm{kg} \mathrm{SO}_{2} \mathrm{eq}\right]$ & 0.69 & 1.27 & 1.67 & 2.07 & 2.67 \\
\hline 4 & Freshwater eutrophication [kg P eq] & 0.00 & 0.00 & 0.00 & 0.00 & 0.00 \\
\hline 5 & Marine eutrophication [kg N eq] & 0.05 & 0.08 & 0.11 & 0.13 & 0.17 \\
\hline 6 & Human toxicity [kg 1,4-DCB eq] & 2.20 & 4.39 & 5.87 & 7.36 & 9.60 \\
\hline 7 & $\begin{array}{l}\text { Photochemical oxidant formation } \\
\text { [kg NMVOC }]\end{array}$ & 1.27 & 2.20 & 2.84 & 3.48 & 4.43 \\
\hline 8 & $\begin{array}{l}\text { Particulate matter formation }[\mathrm{kg} \\
\text { PM10 eq] }\end{array}$ & 0.28 & 0.52 & 0.68 & 0.84 & 1.08 \\
\hline 9 & $\begin{array}{c}\text { Terrestrial ecotoxicity }[\mathrm{kg} \text { 1,4-DCB } \\
\text { eq] }\end{array}$ & 0.01 & 0.02 & 0.02 & 0.03 & 0.04 \\
\hline 10 & $\begin{array}{c}\text { Freshwater ecotoxicity [kg 1,4-DCB } \\
\text { eq] }\end{array}$ & 0.01 & 0.02 & 0.03 & 0.03 & 0.04 \\
\hline 11 & Marine ecotoxicity [kg 1,4-DCB eq] & 0.06 & 0.16 & 0.23 & 0.30 & 0.40 \\
\hline 12 & Ionising radiation [kBq U235 eq] & 0.00 & 0.49 & 0.81 & 1.14 & 1.63 \\
\hline 13 & Agricultural land occupation $\left[\mathrm{m}^{2} \mathrm{a}\right]$ & 0.00 & 0.00 & 0.00 & 0.00 & 0.00 \\
\hline 14 & Urban land occupation $\left[\mathrm{m}^{2} \mathrm{a}\right]$ & 0.00 & 0.00 & 0.00 & 0.00 & 0.00 \\
\hline 15 & Natural land transformation $\left[\mathrm{m}^{2}\right]$ & 0.00 & 0.00 & 0.00 & 0.00 & 0.00 \\
\hline 16 & Water depletion $\left[\mathrm{m}^{3}\right]$ & 0.00 & 0.02 & 0.03 & 0.04 & 0.06 \\
\hline 17 & Metal depletion [kg Fe eq] & 0.00 & 0.05 & 0.08 & 0.11 & 0.16 \\
\hline 18 & Fossil fuel depletion [kg oil eq] & 0.00 & 63.07 & 105.12 & 147.17 & 210.24 \\
\hline
\end{tabular}


Table 8. Summary GWP and emission savings for the 3 scenarios.

\begin{tabular}{|c|c|c|c|c|c|c|c|}
\hline Per MWh of energy & Grid & AD & NG & Biogas & Petrol & Diesel & Biomethane \\
electricity & Electricity & Grid & Grid $^{2}$ & Fuel & Fuel $^{3}$ & Fuel $^{4}$ \\
\hline Climate change $\left[\mathrm{kg} \mathrm{CO}_{2}\right.$ eq] & 597.11 & 302.77 & 450.71 & 259.67 & 701.82 & 654.91 & 178.35 \\
\hline Savings $\left[\mathrm{kg} \mathrm{CO}_{2}\right.$ eq] & & & & & & & 523.48 \\
& N/A & 294.34 & N/A & 191.04 & N/A & N/A & 476.56 \\
\hline
\end{tabular}

Notes for table 8:

1. Avoided GHG emissions from AD Electricity (Table 2: 597.11-302.77 $=294.34 \mathrm{~kg} \mathrm{CO}_{2}$ eq)

2. Avoided GHG emissions from Biogas to Grid (Table 3: 450.71-259.67=191.04 $\mathrm{kg} \mathrm{CO}_{2}$ eq)

3. Avoided GHG emissions from Biomethane to Petrol Fuel (Table 4: $701.82-178.35=523.48 \mathrm{~kg}$ $\mathrm{CO}_{2}$ eq)

4. Avoided GHG emissions from Biomethane Diesel Fuel (Table 4 654.91-178.35 $=476.56 \mathrm{~kg}$ $\mathrm{CO}_{2}$ eq) 
